Article

\title{
The First Stages of Chemical and Electrochemical Aniline Oxidation-Spectroscopic Comparative Study
}

\author{
Zuzana Morávková *, Ivana Šeděnková and Patrycja Bober(1) \\ Institute of Macromolecular Chemistry, Czech Academy of Sciences, Heyrovsky Sq. 2, \\ 16806 Prague, Czech Republic; sedenkova@imc.cas.cz (I.Š.); bober@imc.cas.cz (P.B.) \\ * Correspondence: moravkova@imc.cas.cz
}

Received: 20 February 2020; Accepted: 12 March 2020; Published: 19 March 2020

check for updates

\begin{abstract}
There are several types of aniline oligomers that can be formed in the early stages of aniline oxidation: linear oligomers with repeating units joined in para positions, and various branched and polycyclic oligomers, being the two most important groups. The fraction of these different oligomeric groups depends upon the reaction conditions of aniline oxidation. The aim of this study was to analyze the first products of the chemical and electrochemical oxidation of aniline at the (starting) $\mathrm{pH} 1$ and 7, in order to specify the conditions of the formation of phenazine-like oligomers, and to test the theory that they have an important role in polyaniline film formation. We have confirmed that phenazine-like oligomers do not form at $\mathrm{pH} 1$, neither in the chemical nor the electrochemical oxidation of aniline; however, they form in both chemical and electrochemical oxidation of aniline at $\mathrm{pH}$ 7. Phenazine-like oligomers are thus definitely not necessary intermediates for PANI film formation, not even in the chemical polymerization of aniline. Finally, the redox behavior of phenazine-like oligomers was demonstrated in a medium at $\mathrm{pH} 1$.
\end{abstract}

Keywords: polyaniline; aniline oligomer; electrochemistry; FTIR; SERS

\section{Introduction}

Polyaniline (PANI) is one of the most studied conducting polymers. It has a wide range of applications, including wastewater processing [1,2], catalysis [2], sensing [3-6], biomedical [5,7,8], optical [9] and electrochemical [9-13] applications. Many of these areas require PANI in the form of a thin film.

PANI and aniline oligomer (AO) thin films can be prepared by in-situ chemical [14-16] or electrochemical $[15,16]$ polymerization. In both cases the type of formed product depends upon the initial $\mathrm{pH}[17,18]$ : In an acidic medium, the linear PANI chain is formed with aniline units coupled exclusively in the para positions $[16,17,19-22]$. On the other hand, in neutral or basic media, ortho-coupling becomes possible in addition to para-coupling, which leads to a formation of a mixture of various AO structures $[19,20,22,23]$.

The first stages of aniline oxidation influence the morphology of the obtained PANI powders and films [24]. At low $\mathrm{pH}$, the granular morphology of PANI is observed on PANI powder samples [17,20,24], while the films display the brush-like ordering of the PANI chains [15]. The chemical oxidation of PANI in a neutral medium or a medium of moderate acidity leads to the formation of nanotubes and nanorods. There are several theories explaining the mechanism of the linear structure formation $[17,20,24,25]$. In basic media, hollow microspheres of AOs are formed [24]. However, in this case, the morphology is caused more likely by the poor solubility of aniline in the basic medium than by the properties of AOs.

Specific AO species based on the $N$-phenylphenazinium cation were believed to be responsible for the tubular morphology formation and film adherence to the substrates $[17,20,26-28]$. However, aniline dimer was proven to be the adsorbing species in electrochemical aniline oxidation at any 
$\mathrm{pH}$ [18]. The PANI film obtained by the in-situ chemical oxidation of aniline at very low $\mathrm{pH}$ also seems to contain no $\mathrm{N}$-phenylphenazinium cation structures. However, as only finished film was studied in this case, Raman spectra without surface-enhanced Raman scattering (SERS) enhancement brings restricted information about the first products [29]. These findings lead to the question whether the $N$-phenylphenazinium cation-based AOs play any role in film formation within in-situ chemical aniline oxidation.

If the absence of the N-phenylphenazinium cation in the PANI films prepared by in-situ chemical polymerization is proven, the in-situ chemical PANI film preparation must then be equal to the electrochemical method from the PANI-chain linearity point of view. Beside this, there are other relevant factors in the chemical and electrochemical preparation of PANI films that influence the applicability of these methods: (1) Electrochemical PANI film preparation requires a conducting substrate that serves as a working electrode in the polymerization cell. The in-situ chemical polymerization of aniline operates at any surface, including e.g., glass, textiles, the solution-air interface, etc. [14,16]. (2) In the case of the electrochemical method, PANI is only formed at the electrode, while during the chemical method, PANI also forms as a precipitate in the bulk solution, increasing reactant consumption for a unit of surface area of formed PANI film [14].

Although chemically prepared AOs have already been studied by various methods $[27,28,30]$, a SERS study of the reaction kinetics has not been performed yet. The presence of $N$-phenylphenazinium cation-based AOs during chemical oxidation has been proven only by its detection in fully formed film [28]. In the case of the electrochemical oxidation of aniline, only studies in low $\mathrm{pH}$ and dimerization are available $[15,22,31-33]$. Studies of electrochemical aniline oxidation at neutral $\mathrm{pH}$ are also limited simply to the detection of $N$-phenylphenazinium cation [18,34].

In this work, we thoroughly study and compare the first products of both the chemical and electrochemical oxidation of aniline at $\mathrm{pH} 1$ and 7 with the methods of in-situ and ex-situ FTIR and Raman spectroscopies. The role of phenazine-like oligomers in the process of aniline oxidation is better specified.

\section{Materials and Methods}

\subsection{Chemicals}

Aniline ( $\geq 99.5 \%$ ) and sulfuric acid ( $\geq 97.5 \%$ ) were purchased from Sigma-Aldrich. Sodium sulfate and ammonium persulfate (APS) were obtained from Lach-Ner. All chemicals were used as received, without any further purification. Ultrapure Q-water ultra-filtered in a Mili-Q Gradient A10 system (Millipore, Molsheim, France) was used for the preparation of solutions.

\subsection{Chemical Preparation}

The chemical oxidation of $0.05 \mathrm{M}$ aniline with $0.0625 \mathrm{M}$ APS was performed in an aqueous solution of $0.1 \mathrm{M}$ sulfuric acid ( $\mathrm{pH} 1$ ) or $0.1 \mathrm{M}$ sodium sulfate $(\mathrm{pH}$ 7) at room temperature. Both monomer and oxidant were separately dissolved in the required solution to $50 \mathrm{~mL}$, then these solutions were mixed to start the oxidation of aniline. The reaction mixture was left at rest to polymerize. During the polymerization the $\mathrm{pH}$ and temperature of the reaction mixture were recorded using the HI- 4221 Research Grade Bench pH and ORP Meter (Hanna Instruments) to assess the progress of reaction. The open circuit potential (OCP) measurements were conducted in a two-electrode setting with a platinum working electrode and $\mathrm{Ag} / \mathrm{AgCl}$ counter electrode.

Suitable glass windows for UV-vis and the modified electrode (see below) for SERS measurement were placed in the reaction mixture. The supports were removed from the reaction mixture at given times, rinsed with water or $0.1 \mathrm{M}$ sulfuric acid for the $\mathrm{pH} 7$ and $\mathrm{pH} 1$ experiments, respectively, and the film of AOs or PANI was characterized by UV—vis and SERS spectroscopy. 


\subsection{Electrochemical Preparation}

Electrochemical oxidation of aniline was carried out in a Raman spectroelectrochemical cell in an aqueous solution of $0.05 \mathrm{M}$ aniline and $0.1 \mathrm{M}$ sulfuric acid ( $\mathrm{pH} 1$ ) or $0.1 \mathrm{M}$ sodium sulfate ( $\mathrm{pH} 7)$. The cell consisted of the SERS golden working sheet-electrode, platinum wire counter electrode and $\mathrm{Ag} / \mathrm{AgCl}$ pseudo-reference electrode. All potentials are given versus the $\mathrm{Ag} / \mathrm{AgCl}$ pseudo-reference electrode. A $1 \mathrm{~mm}$ thin glass optical cuvette was used as a vessel. The usage of this optical cuvette enables us to focus the Raman laser on the surface of the electrode, and to study the electrochemically-formed films of AOs and polyaniline in situ. The potentiodynamic method of PANI deposition was applied. For further Raman spectroelectrochemical (SEC) study, $0.1 \mathrm{M}$ sulfuric acid solution was used as an electrolyte.

\subsection{Electrochemistry}

The electrochemical measurements were controlled by a Bio-logic potentiostat/galvanostat VSP300. During the in-situ Raman spectroelectrochemistry (SEC), the potential was changed at the rate of $10 \mathrm{mV} / \mathrm{s}$ for the measurements with $785 \mathrm{~nm}$ excitation, and $0.7 \mathrm{mV} / \mathrm{s}$ for the measurements with $633 \mathrm{~nm}$ excitation; leading in both cases to the data density of 1 spectrum per $0.04 \mathrm{~V}$ range.

\subsection{FTIR Kinetics}

The chemical polymerization of aniline was studied in the aqueous solutions of $0.1 \mathrm{M}$ sodium sulfate and $0.1 \mathrm{M}$ sulfuric acid. The oxidation of the aniline monomer was followed in situ by attenuated total reflection (ATR) infrared spectroscopy, using a Thermo Nicolet NEXUS 870 spectrometer with an MCT nitrogen-cooled detector. The droplet $(0.75 \mu \mathrm{L})$ of $0.05 \mathrm{M}$ aniline solution was placed on the surface of the ZnSe crystal, and the same amount of $0.0625 \mathrm{M}$ APS solution was added [35]. The spectra were recorded at the resolution of $4 \mathrm{~cm}^{-1}$, and 32 scans were accumulated for each spectrum. The spectra were measured continuously, where each spectrum took $12.75 \mathrm{~s}$. The spectrometer was purged with dry air.

\subsection{Raman Spectroscopy}

Raman spectra were collected on a Renishaw inVia Reflex Raman spectrometer (Leica DM LM microscope; objective magnification $\times 50$ ) with a HeNe $633 \mathrm{~nm}$ laser (holographic grating 1800 lines $\mathrm{mm}^{-1}$ ) and diode $785 \mathrm{~nm}$ laser (holographic grating 1200 lines $\mathrm{mm}^{-1}$ ).

Where relevant, a selected spectral region was deconvoluted with gaussian peaks on a linear baseline using an octave script.

\subsection{SERS Substrate Preparation}

The SERS substrates were prepared by the following procedure, based mainly on the work of Liu et al. [36]: The gold sheet electrodes were flame cleaned at the point of melting, and then by potential cycling in $1 \mathrm{M}$ sulfuric acid. Then it was cycled in $1 \mathrm{M}$ potassium chloride in hydrochloric acid tuned to $\mathrm{pH} 1$ ( $0.1 \mathrm{M}$ hydrochloric acid). The cycle consists of $2 \mathrm{~V} / \mathrm{s} \mathrm{ramp}$ form $-0.6 \mathrm{~V}$ to $1 \mathrm{~V}, 1 \mathrm{~s}$ hold at $1 \mathrm{~V}, 2 \mathrm{~V} / \mathrm{s}$ ramp from $1 \mathrm{~V}$ to $-0.6 \mathrm{~V}$ and $2 \mathrm{~s}$ hold at $-0.6 \mathrm{~V}$; it is repeated ca 200 times depending on the size of the electrode. The counter electrode is platinum sheet, and $\mathrm{Ag} / \mathrm{AgCl}$ is used as pseudo-reference.

\section{Results}

In order to compare the chemical and electrochemical oxidation of aniline as reliably as possible, we have brought some typical conditions of chemical oxidation to our electrochemical experiment, and vice versa. The electrochemical oxidation of aniline is typically conducted in a strongly acidic medium ( $0.1 \mathrm{M}$ sulfuric acid- $\mathrm{pH} 1$, in our case) and the $\mathrm{pH}$ is maintained throughout the reaction [15]. The chemical oxidation of aniline, on the other hand, is initiated in media with acidity varying from ca $\mathrm{pH} 2$ to 8 [17,24]. The $\mathrm{pH}$ also changes during the chemical oxidation of aniline with APS as sulfuric acid is a byproduct. 
In our experiment, we start both electrochemical and chemical aniline oxidations in $0.1 \mathrm{M}$ sulfuric acid ( $\mathrm{pH} 1)$ and $0.1 \mathrm{M}$ sodium sulfate ( $\mathrm{pH} 7)$. The sodium sulfate was chosen as an electrolyte for the electrochemical experiment to keep the condition of electrochemical polymerization close to the conditions of chemical polymerization.

\subsection{Kinetics of Chemical Aniline Oxidation at $\mathrm{pH} 1$ and 7}

The course of chemical oxidation of aniline can be followed by temperature [37], OCP [21] and $\mathrm{pH}$ [37], providing information on the reaction rate and distinguishing its phases (Figure 1).

The oxidation of aniline started at $\mathrm{pH} 1$ has an induction period of ca $3 \mathrm{~min}$. Then, the temperature and $\mathrm{pH}$ change dramatically (Figure $1 \mathrm{~b}, \mathrm{c}$ ). This is connected with the formation of growing chains in the pernigraniline form. After another ca $10 \mathrm{~min}$, potential drops and the decrease of $\mathrm{pH}$ slows down (Figure $1 \mathrm{a}, \mathrm{b}$ ) as the transformation of pernigraniline to emeraldine becomes the prevailing reaction. Temperature, reflecting changes in the bulk rather than on interfaces in contrast to $\mathrm{pH}$ and OCP, starts dropping almost an hour after the beginning of the experiment (not shown). This demonstrates the fact that oxidation of aniline in acidic medium is faster at interfaces than in solution.

When starting at $\mathrm{pH} 7$, the progress of the reaction seems to be much faster (Figure 1). The potential drops to zero within the first minute, and then increases gradually during the next ca $15 \mathrm{~min}$. Then the electrodes are probably passivated, as only artifacts are observed in the OCP measurement. The $\mathrm{pH}$ drops during the first $15 \mathrm{~min}$, and then the rate of decrease slows down. As the temperature follows the same trend as $\mathrm{pH}$ and potential, we can assume that for this $\mathrm{pH}$ range the rate of aniline oxidation is similar on interfaces and in solution.
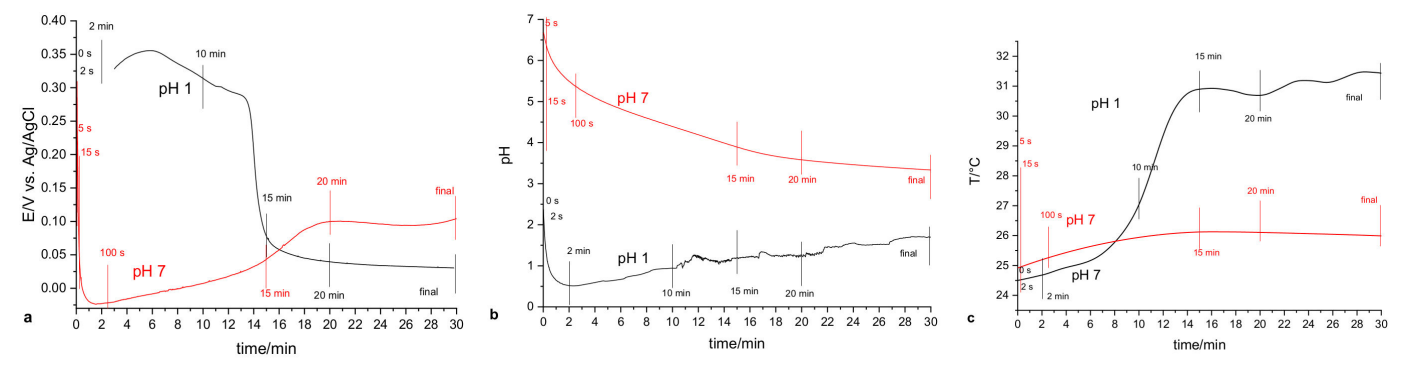

Figure 1. Open circuit potential (OCP) (a), $\mathrm{pH}(\mathbf{b})$ and temperature (c) profile of the chemical oxidations of aniline at starting $\mathrm{pH} 1$ and 7.

\subsection{FTIR Kinetic Study of the Chemical Oxidation of Aniline}

To study the chemical oxidation of aniline in detail, the molecular structure of the products was followed in situ by ATR-FTIR spectroscopy. The spectrum of the reaction mixture, measured before any changes could be observed (i.e., the spectrum of reactants), was subtracted from all spectra. The differential spectra are presented in the Figures 2 and 3; complete band assignment is summarized in Table 1.

In the neutral medium ( $\mathrm{pH} 7$ ), the oxidation of aniline starts immediately after the addition of the APS solution to the aniline solution. The main bands observed at $1509 \mathrm{~cm}^{-1}$ and $1586 \mathrm{~cm}^{-1}$ are assigned to the stretching vibration of the $-\mathrm{C}=\mathrm{C}-$ bond of quinonoid and benzenoid rings, respectively. The intensity of the band connected with the quinonoid ring is significantly lower than the intensity of the benzenoid band. Two bands typical for nanostructured PANI material are observed at $1445 \mathrm{~cm}^{-1}$ (skeletal vibration of the substituted aromatic ring) and $1415 \mathrm{~cm}^{-1}$ (phenazine-like ring stretching vibrations).

The band at $1707 \mathrm{~cm}^{-1}$ observed in several of the first spectra corresponds to the stretching vibration of the carbonyl group on the quinone ring. The intensity of the band decreases during the proceeding reaction. The band assigned to the $\mathrm{C}-\mathrm{N}$ bond stretching next to the aromatic ring at $1365 \mathrm{~cm}^{-1}$ is shifted from the typical position at $1374 \mathrm{~cm}^{-1}$ expected in PANI. This can be attributed to the 1,2,4-substituted ring formation instead of the typical 1,4-substituted ring. The higher intensity of the 
band at $861 \mathrm{~cm}^{-1}$ (out-of-plane $\mathrm{C}-\mathrm{H}$ bending vibration on the aromatic ring), together with the band at $846 \mathrm{~cm}^{-1}$, signifies the higher fraction of the tri-substituted aromatic rings in the molecular structure.

As the oxidation of aniline proceeds, the position of the bands remains practically unchanged, and the only difference between bands in the first spectrum and the spectrum measured after 15 min of the reaction is their intensity.
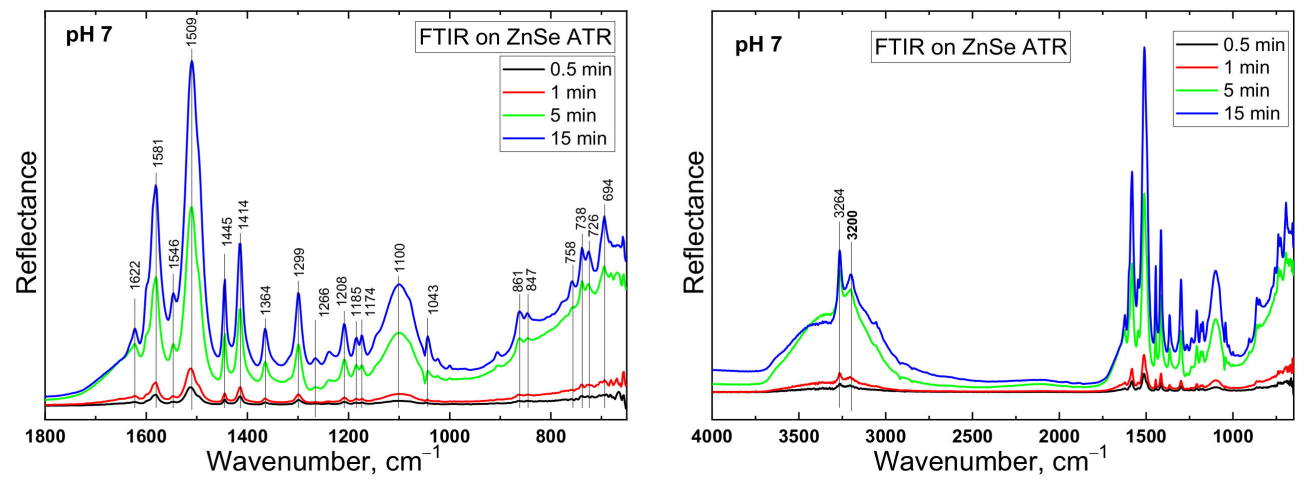

Figure 2. Selected spectra representing the evolution of attenuated total reflection (ATR) Fourier transform infrared (FTIR) spectra of aniline oxidation at $\mathrm{pH} 7$ on ZnSe crystal. The spectrum of the reaction mixture was subtracted from each spectrum.

Table 1. Assignment of the FTIR bands in the in-situ FTIR experiment at $\mathrm{pH} 7$.

\begin{tabular}{|c|c|c|c|}
\hline Acid & Assignment & Product & References \\
\hline 3264 & $v(\mathrm{~N}-\mathrm{H})$ & $\begin{array}{c}\text { Hydrogen bond to } \mathrm{C}=\mathrm{O} \text { of } \\
p \text {-benzoquinone }\end{array}$ & [35] \\
\hline 3200 & $v(\mathrm{~N}-\mathrm{H})$ & $\begin{array}{l}\text { Hydrogen bonded to } \\
\text { sulfonic group }\end{array}$ & [35] \\
\hline 1622 & $\begin{array}{c}\delta(\mathrm{NH}) \text { of primary aromatic amines; } v(\mathrm{C}=\mathrm{O}) \\
\text { quinonoid }\end{array}$ & $\mathrm{AO}$, monomer & [38] \\
\hline 1581 & $v(-C=C-)$ of the $Q$ ring & linear chain & {$[39,40]$} \\
\hline 1546 & $v(C-C)$ of the $B$ ring or phenazine-like unit & $\mathrm{AO}$ & [39] \\
\hline 1509 & $v(-C=C-)$ of the $B$ ring & linear chain & [39] \\
\hline 1445 & $v$ (ring) of the substituted aromatic ring & Phenazine-like structures & {$[39,41,42]$} \\
\hline 1414 & $\begin{array}{c}\begin{array}{c}v(\text { phenazine ring }), \\
\text { group }\end{array} \\
\text { g(C-C) next to the imine }\end{array}$ & Phenazine-like structures & {$[39,41,42]$} \\
\hline 1365 & $v(\mathrm{C}=\mathrm{N})$ next to the aromatic ring & $1,2,4$-substituted ring & [38] \\
\hline 1299 & $v($ arom. amines $)$ & $\begin{array}{c}p \text {-benzoquinone, } \\
\text { phenazine-like structures }\end{array}$ & [38] \\
\hline 1266 & $v(\mathrm{C}-\mathrm{N}), \delta(\mathrm{C}-\mathrm{H})$ in the $\mathrm{Q}$ ring, $v(\mathrm{C}-\mathrm{O})$ & $\begin{array}{c}\text { primary amines, } \\
p \text {-benzoquinone, phenol }\end{array}$ & {$[17,38,39]$} \\
\hline 1208 & $v(\mathrm{C}-\mathrm{N})$ & primary amines & [17] \\
\hline $1185 / 1174$ & $\delta(\mathrm{C}-\mathrm{H})$ in plane & quinone diimine structures & [39] \\
\hline 1100 & $v\left(\mathrm{SO}_{4}{ }^{2-}\right)$ & ammonium sulfate & {$[43,44]$} \\
\hline 1043 & $v\left(\mathrm{SO}_{4}{ }^{2-}\right)$ & sulfated aromatic rings & {$[43,44]$} \\
\hline 861 & $\gamma(\mathrm{C}-\mathrm{H})$ out of plane & tri-substituted aromatic ring & [45] \\
\hline 847 & $\gamma(\mathrm{C}-\mathrm{H})$ out of plane & di-substituted aromatic ring & [45] \\
\hline 758 & $\gamma(\mathrm{C}-\mathrm{H})$ & linear chain & [46] \\
\hline
\end{tabular}

The evolution of spectra measured during aniline oxidation in sulfuric acid (pH 1) is significantly different (Figure 3, Table 2). The intensive bands appearing earliest in the differential spectrum 
are connected with water $\left(1630 \mathrm{~cm}^{-1}\right)$, aniline $\left(1499 \mathrm{~cm}^{-1}\right)$ and APS $\left(1048 \mathrm{~cm}^{-1}\right)$. The fact that the bands of reactants and water are present, even in the differential spectra, can be assigned to two factors: (1) The droplet of the reaction mixture spreads wider on the ATR crystal during first minute of the oxidation reaction, which influences the subtraction, and (2) the reactants are adsorbed on the crystal surface. Both factors play their role. The presence of water bands is exclusively caused by the higher area of the droplet-crystal interface. On the other hand, due to the adsorption of the reactants, the intensities of the bands from aniline and APS are considerably higher than expected based on the reactant spectra. We do not observe this behavior in the evolution of spectra measured in the salt solution ( $\mathrm{pH} 7$ ), as the first products are formed fast enough to cover the crystal-solution and solution-air interfaces, and stabilize the shape of the droplet.

The first distinguishable bands which are not connected with the reactants are observed after 2 min of oxidation. The band at about $1110 \mathrm{~cm}^{-1}$ is assigned to the vibration modes of ammonium sulfate, the product of the APS decomposition. The broad, weak band found at about $1250 \mathrm{~cm}^{-1}$ is most probably connected with the vibration of amine groups in the aromatic amines.

After $2 \mathrm{~min}$, the band at $1571 \mathrm{~cm}^{-1}$ (stretching vibration of quinonoid rings), the weak, broad band at about $1500 \mathrm{~cm}^{-1}$ (vibration of benzenoid ring in the PANI structure), and bands at $1376 \mathrm{~cm}^{-1}$ (imine structure in pernigraniline), $1285 \mathrm{~cm}^{-1}$ and $1260 \mathrm{~cm}^{-1}$, appear. The broad band at about $1100 \mathrm{~cm}^{-1}$ and a sharp band at $1047 \mathrm{~cm}^{-1}$ are connected with formation of ammonium sulfate. The intensity ratio of the quinonoid and benzenoid ring stretching bands corresponds to the higher content of the quinonoid rings observed in the first stages of chemical aniline oxidations [17]. A shoulder on the broad band at $1490 \mathrm{~cm}^{-1}$, at about $1460 \mathrm{~cm}^{-1}$ corresponding to pernigraniline [46,47], is also observed.
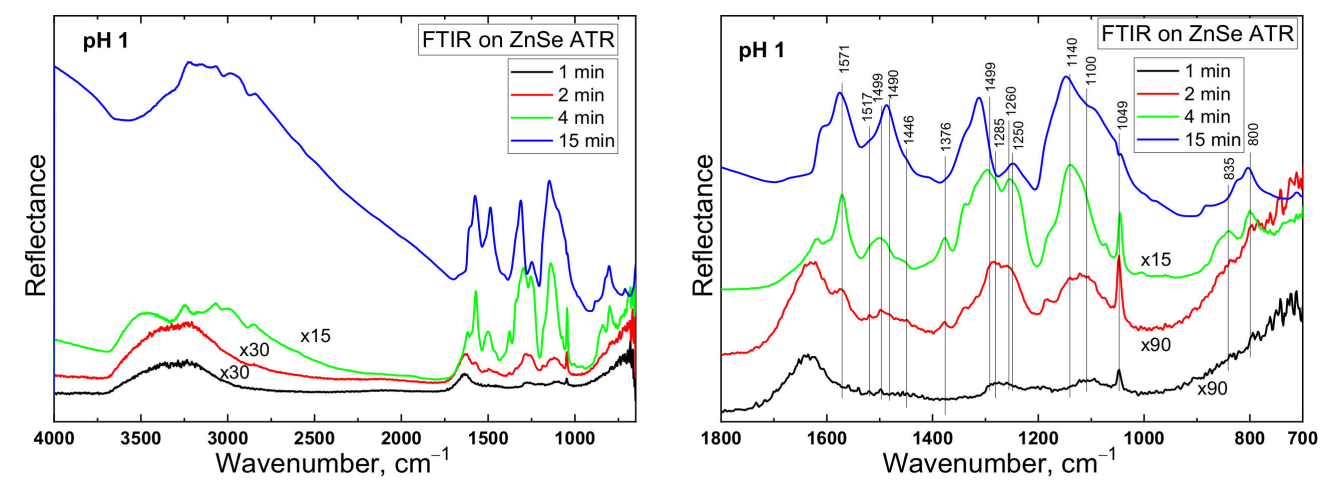

Figure 3. Selected spectra representing the evolution of ATR FTIR spectra of aniline oxidation at $\mathrm{pH} 1$ on $\mathrm{ZnSe}$ crystal. The spectrum of the reaction mixture was subtracted from each spectrum.

The main bands described above remain present also after 4 min of polymerization, with their positions slightly shifted. The band of quinonoid ring stretching at $1571 \mathrm{~cm}^{-1}$ is sharp, and one of the most intensive in the spectrum. The band linked to the benzenoid ring is broad, with its shoulder at about $1460 \mathrm{~cm}^{-1}$. The band at $1376 \mathrm{~cm}^{-1}$ of the imine structure (pernigraniline) $[47,48]$ is well pronounced. The maxima of the broad band between 1200 and $1300 \mathrm{~cm}^{-1}$ are shifted to 1296 and $1254 \mathrm{~cm}^{-1}$. The maximum of the ammonium sulfate band is at $1140 \mathrm{~cm}^{-1}$. The sharp band linked to the sulfate ions is at $1050 \mathrm{~cm}^{-1}$. The bands of out of plane vibration are shifted to 840 and $800 \mathrm{~cm}^{-1}$. In this spectrum, the structure of the $\mathrm{C}-\mathrm{H}$ and $\mathrm{N}-\mathrm{H}$ stretching bands in the region $3400-2800 \mathrm{~cm}^{-1}$ is developed. The bands have maxima at $3245,3071,3003$ and $2849 \mathrm{~cm}^{-1}$. The maximum at $3465 \mathrm{~cm}^{-1}$ is connected with the $\mathrm{OH}$ vibration of water. 
Table 2. Assignment of the FTIR bands in the in-situ FTIR experiment at $\mathrm{pH} 1$.

\begin{tabular}{cccc}
\hline Acid & Assignment & Product & References \\
\hline 1571 & $v(-\mathrm{C}=\mathrm{C}-)$ of the $\mathrm{Q}$ rings & neutral AO & {$[39,40]$} \\
\hline 1517 & $v(\mathrm{C}-\mathrm{C})+\delta(\mathrm{C}-\mathrm{H})$ & doped dimer & {$[39]$} \\
\hline 1499 & $v(-\mathrm{C}=\mathrm{C}-)$ of the $\mathrm{B}$ rings & neutral AO & {$[40]$} \\
\hline 1490 & $v(-\mathrm{C}=\mathrm{C}-)$ of the $\mathrm{B}$ rings & protonated PANI chain & {$[40]$} \\
\hline 1460 sh & $v($ ring $)$ substituted aromatic ring & pernigraniline & {$[47,48]$} \\
\hline 1376 & $v(\mathrm{C}=\mathrm{N})$ next to the aromatic ring & pernigraniline & {$[47,48]$} \\
\hline $1312 / 1338$ & $v(\mathrm{C} \approx \mathrm{N})$ & PANI chain/AO (delocalization length $)$ & {$[39]$} \\
\hline 1302 & $v(\mathrm{C}-\mathrm{N})$ & secondary aromatic amines & {$[45]$} \\
\hline 1285 & $\delta(\mathrm{N}-\mathrm{H})+v(\mathrm{C}-\mathrm{N})$ & Primary amino group & {$[38]$} \\
\hline 1260 & $\delta(\mathrm{C}-\mathrm{H})$ in the $\mathrm{Q}$ ring, $v(\mathrm{C}-\mathrm{N}), v(\mathrm{C}-\mathrm{O})$ & Primary amino group in AO, & {$[17,38,39]$} \\
\hline 1245 & $v\left(\mathrm{C}-\mathrm{N}^{+}\right)$ & $p$-benzoquinone & {$[49]$} \\
\hline 1148 & $v\left(=\mathrm{NH}^{+}-\right)$ & PANI salt & {$[38,39]$} \\
\hline 1100 & $v\left(\mathrm{SO}_{4}{ }^{2-}\right)$ & protonate PANI chain & {$[43,44]$} \\
\hline 1049 & $v\left(\mathrm{SO}_{4}{ }^{2-}\right)$ & ammonium sulfate & {$[43,44]$} \\
\hline 835 & $\gamma(\mathrm{C}-\mathrm{H})$ & sulfated aromatic rings & {$[45]$} \\
\hline 800 & $\gamma(\mathrm{C}-\mathrm{H})$ & 1,2 -disubstituted ring & {$[39]$} \\
\hline
\end{tabular}

The spectra evolve rather evenly afterwards, until ca $15 \mathrm{~min}$ reaction time. The overall intensity increases significantly, and the absorption above $2000 \mathrm{~cm}^{-1}$ is observed, typical of the conducting form of PANI. The intensity of the benzenoid band increases faster than the intensity of the quinonoid band, corresponding to the transformation to the emeraldine form of PANI. The position of the benzenoid bands is then shifted to $1488 \mathrm{~cm}^{-1}$, while the position of the quinonoid bands remains at $1572 \mathrm{~cm}^{-1}$. The band at $1376 \mathrm{~cm}^{-1}$ is suppressed, and only a shoulder remains. The intensive bands at $1312 \mathrm{~cm}^{-1}$ and the band at $1241 \mathrm{~cm}^{-1}$ are connected with delocalization of $\pi$-electrons, and are linked to the protonation of the PANI chain. The most intensive band at $1141 \mathrm{~cm}^{-1}$ is assigned to the vibration of the $=\mathrm{NH}^{+}$- group. The band at $801 \mathrm{~cm}^{-1}$ in the region of the out-of-plane vibrations remains in the spectrum. In general, the differential spectrum obtained after about $15 \mathrm{~min}$ of the oxidation reaction is in accordance with the spectrum of emeraldine PANI film prepared in the oxidation reaction in sulfuric acid.

\subsection{UV-Visible Absorption Spectroscopy of Chemically Oxidated Aniline}

In contrast to FTIR, UV-visible absorption and SERS kinetics of the chemical oxidation of aniline could not be conducted in situ, as the solution becomes opaque during the reaction, and the bulk material rather than the film is analyzed. The chemical oxidation of aniline was conducted in a wide beaker. Glass slides and SERS substrates were introduced in the medium at the very beginning. Based on the kinetics, certain times were selected for removal of the substrates from the reaction medium.

The spectra were normalized, and in the case of $\mathrm{pH} 7$ also shifted for clarity, the total absorbance of the sample was strongly dependent on the film thickness.

Significant differences are observed between UV-Vis absorption spectra obtained on glass substrates removed from the reaction mixtures at $\mathrm{pH} 1$ and 7 at various times (Figure 4). Whereas in the strongly acidic medium, PANI in the emeraldine (15 min, final) $[41,50-53]$ and pernigraniline (2 $\mathrm{min}, 10 \mathrm{~min}$ ) [48,52] salt form is observed. The evolution of the UV-Visible absorption spectra of the product formed at $\mathrm{pH} 7$ are more complex. After $15 \mathrm{~s}$ of reaction, a spectral shape corresponding to emeraldine salt is observed. After $100 \mathrm{~s}$, a relatively narrow band at $425 \mathrm{~nm}$ appears, which corresponds to the charged phenazine-like AOs [54,55]. 
This band is then present till the end of the reaction, with only minor shifts in position. The shoulder at $480 \mathrm{~nm}$ observed in the spectra obtained after 15 and $20 \mathrm{~min}$ of reaction is attributed to radical cations of aniline-type dimer [54]. The soluble dimer intermediates were clearly not washed off properly after the substrate removal from the reaction mixture.
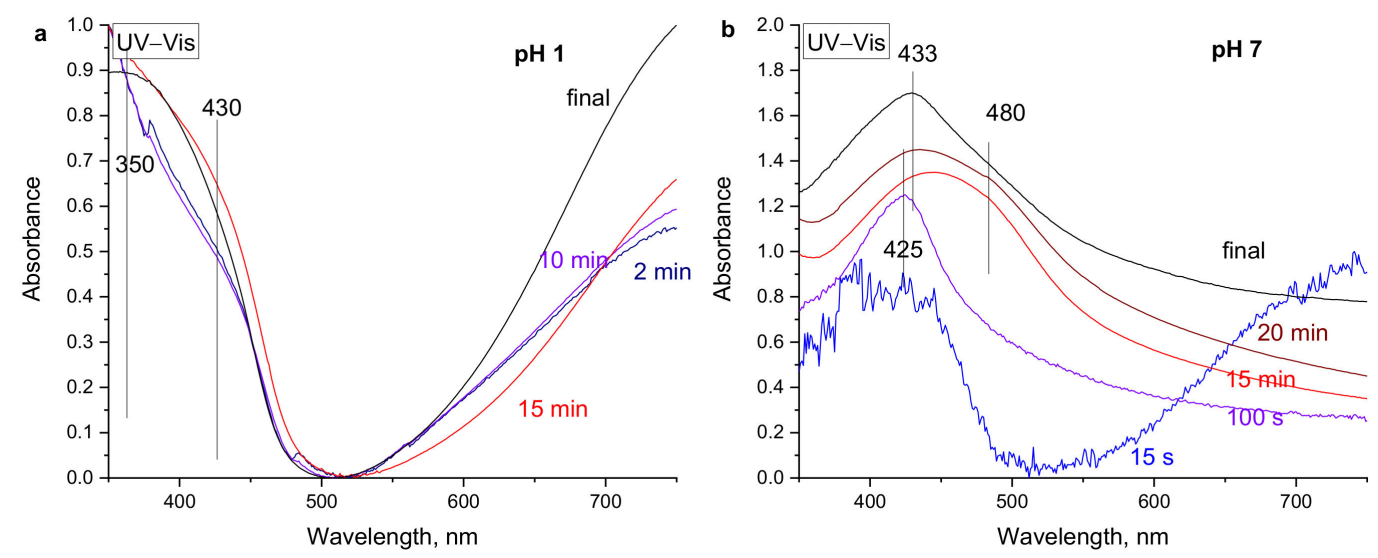

Figure 4. UV-Visible absorption spectra of chemically oxidized aniline films on glass removed from the reaction mixture of starting $\mathrm{pH} 1(\mathbf{a})$ and $7(\mathbf{b})$ at various times after mixing. The spectra are normalized for clarity.

\subsection{Raman Spectra Obtained on SERS Electrodes Removed from the Media at Different Times of Chemical Aniline Oxidation}

Raman spectra of the products of aniline oxidation on SERS electrodes at our starting $\mathrm{pH} 7$ excited with the $785 \mathrm{~nm}$ laser line (Figure 5a, Table 3), vaguely resemble those of emeraldine salt. The $785 \mathrm{~nm}$ excitation line is in resonance with charged emeraldine and pernigraniline-like structures, making the semiquinonoid $\left(1600 \mathrm{~cm}^{-1}\right)$ and quinonoid rings $\left(1625 \mathrm{~cm}^{-1}\right)$ with charged nitrogen structure $\left(\sim 1370 \mathrm{~cm}^{-1}\right)$ dominant in the spectrum.
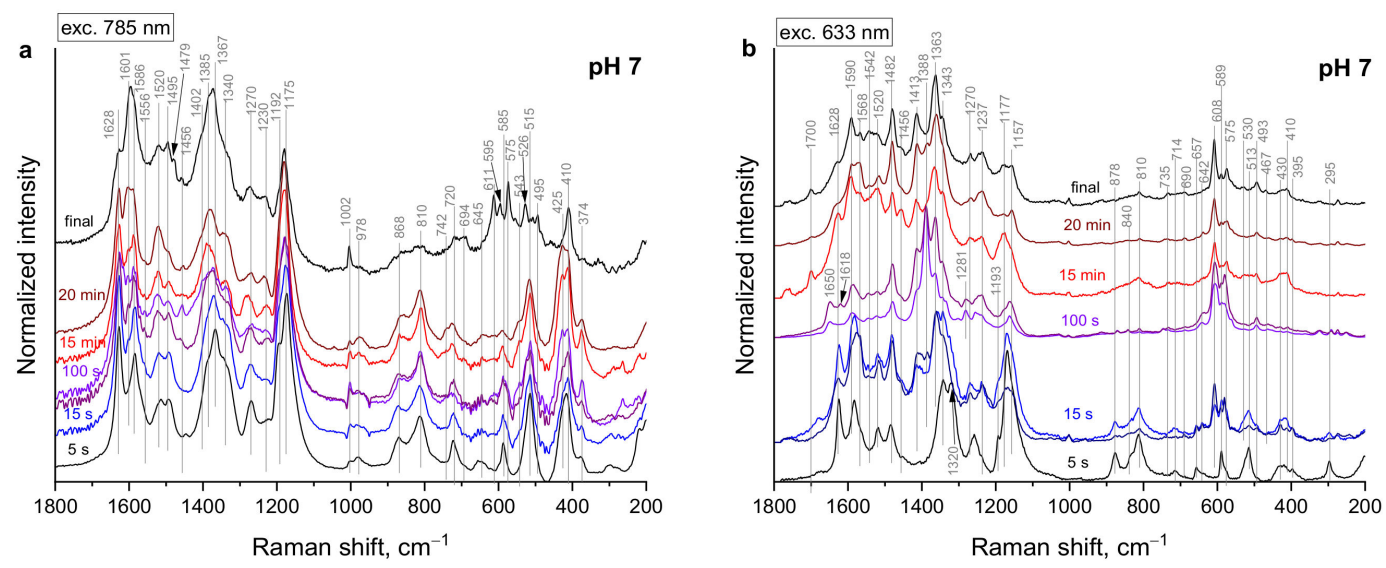

Figure 5. Raman spectra of gold, surface-enhanced Raman scattering (SERS) electrodes removed from the reaction mixture of starting pH 7 at various times. Excitation $785 \mathrm{~nm}(\mathbf{a})$ and $633 \mathrm{~nm}(\mathbf{b})$.

The phenazinium cation-based AOs are resonantly enhanced by the laser line at $633 \mathrm{~nm}$ [28]. Their typical spectral profile strongly dominated by the bands at $1388 / 1363$ and $608 / 575 \mathrm{~cm}^{-1}$ is clearly observed (Figure 5b, Table 3) [28,34]. However, they appear after ca $100 \mathrm{~s}$ of reaction, not immediately (Figure 5). A C $=\mathrm{O}$ stretching band of benzoquinone-based AOs is observed at $1650 \mathrm{~cm}^{-1}$. The spectra obtained after 5 and 15 s of reaction reflect the formation of mainly linear AOs (typical bands at 1628, 1590,1343 and $1177 \mathrm{~cm}^{-1}$ ). This might mean that phenazinium cations are formed later on, or that the phenazine-like AOs is protonated at later phases of the reaction after the $\mathrm{pH}$ drops (Figure $1 \mathrm{~b}$ ). As the 
resonant enhancement is operative only for the protonated species, the neutral $N$-phenylphenazine structure may not be detected. At later stages of the reaction, a complex spectrum of the AO mixture is observed: typical bands of $N$-phenylphenazinium cation $\left(1388 / 1363,608,575 \mathrm{~cm}^{-1}\right)$ and linear emeraldine $\left(1628,1590,1343\right.$ and $\left.1177 \mathrm{~cm}^{-1}\right)$ are observed.

Table 3. Summary of observed Raman peaks-peak positions are rounded to $5 \mathrm{~cm}^{-1}$.

\begin{tabular}{|c|c|c|c|c|}
\hline $633 \mathrm{~nm}$ & $785 \mathrm{~nm}$ & Assignment & Typical Product & Reference \\
\hline 1700 & & $\mathrm{C}=\mathrm{O}$ stretching (overoxidation) & & [43] \\
\hline 1650 & & $\mathrm{n}(\mathrm{C}=\mathrm{O}) \mathrm{BQ}$ & degradation products & {$[43,56]$} \\
\hline 1625 & 1625 & $\begin{array}{l}\mathrm{n} \text { (ring) of the } \mathrm{B} \text { ring next to the } \mathrm{Q} \\
\text { ring in a } \mathrm{Q} \text { structure }\end{array}$ & linear chain, monomer & {$[39,49,57-59]$} \\
\hline 1620 & & $\mathrm{n}(\mathrm{C}-\mathrm{N})$ & monomer & [60] \\
\hline 1605 & 1600 & $\begin{array}{l}\mathrm{n} \text { (ring) of } \mathrm{B} \text { ring in the } \mathrm{SQ} \\
\text { structure }\end{array}$ & linear chain & {$[46,57,58,61]$} \\
\hline 1595 & & SQ n(ring) & linear chain & {$[39,57]$} \\
\hline 1585 & 1585 & $\begin{array}{l}\mathrm{n} \text { (ring) of the } \mathrm{B} \text { ring in the } \mathrm{B} \\
\text { structure }\end{array}$ & $\begin{array}{l}\text { linear chain, aniline cation } \\
\text { radical, phenazine-like } \\
\text { structure }\end{array}$ & {$[28,46,49,57,60,61]$} \\
\hline 1565 & 1555 & $\mathrm{n}$ (ring) $\mathrm{B}$ & linear chain bases & {$[46,57,62]$} \\
\hline 1540 & 1535 & n(ring) $B$ & end-chain B & {$[63,64]$} \\
\hline 1520 & 1520 & $\mathrm{~d}(\mathrm{~N}-\mathrm{H})$ & linear chain & {$[49,57,58,61]$} \\
\hline 1505 & & $\mathrm{~d}(\mathrm{~N}-\mathrm{H})$ & $\begin{array}{l}\text { Charged phenazine-like } \\
\text { structures }\end{array}$ & [65] \\
\hline 1490 & 1495 & $\mathrm{n}(\mathrm{C}=\mathrm{N})$ & emeraldine base & {$[46,57,66]$} \\
\hline 1480 & 1480 & $\mathrm{n}(\mathrm{C}=\mathrm{N}) / \mathrm{d}(\mathrm{C}-\mathrm{H})+\mathrm{n}(\mathrm{C}-\mathrm{C})$ & $\begin{array}{l}\text { emeraldine or pernigraniline } \\
\text { base, aniline cation radical }\end{array}$ & {$[46,57,60,66]$} \\
\hline $1475 / 1485$ & & $\mathrm{n}(\mathrm{C} \sim \mathrm{N})$ & Charged phenazine & [28] \\
\hline 1470 & & $\mathrm{n}(\mathrm{C}=\mathrm{N})$ & linear chain bases & {$[28,46,66]$} \\
\hline 1460 & 1455 & $\mathrm{n}(\mathrm{C}=\mathrm{N})$ & $\begin{array}{c}\text { linear chain bases, } \\
\text { phenazine-like structure }\end{array}$ & {$[46,63,66]$} \\
\hline 1450 & 1450 & $\mathrm{~d}(\mathrm{C}-\mathrm{H})+\mathrm{n}($ ring $)$ & linear chain & {$[46,59]$} \\
\hline $1410 / 1425$ & $1400 / 1415$ & $\begin{array}{l}\mathrm{n}(\mathrm{C} \sim \mathrm{N}) / \mathrm{n} \text { (ring) } \mathrm{Q} / \text { neutral } \\
\text { phenazine }\end{array}$ & linear chain bases & {$[46,57,65]$} \\
\hline 1390 & $1385 / 1390$ & $\mathrm{n}(\mathrm{C} \sim \mathrm{N})$, polaron pair & $\begin{array}{l}\text { highly doped linear chain, } \\
\text { phenazine-like structure }\end{array}$ & {$[59,66]$} \\
\hline 1380 & 1380 & $\mathrm{n}(\mathrm{C} \sim \mathrm{N})$, localized polaron & $\begin{array}{l}\text { linear chain, aniline cation } \\
\text { radical }\end{array}$ & {$[59,60]$} \\
\hline 1365 & 1370 & $\mathrm{n}(\mathrm{C} \sim \mathrm{N})$, localized polaron & phenazine-like structure & [28] \\
\hline $1335 / 1355$ & $1335 / 1340$ & $\begin{array}{l}\mathrm{n}(\mathrm{C} \sim \mathrm{N}) \text {, delocalized polaron; } \\
\mathrm{d}(\mathrm{C}-\mathrm{H}) \mathrm{B}\end{array}$ & linear chain/base & {$[46,49,57,58,61]$} \\
\hline 1320 & & $\mathrm{n}(\mathrm{C} \sim \mathrm{N})$, delocalized polaron & linear chain & {$[49,57,58,61]$} \\
\hline 1280 & & $d(C-H) B$ & linear chain, aniline & {$[46,60]$} \\
\hline $1260 / 1270$ & 1270 & $d(C-H) Q+P$ & $\begin{array}{c}\text { linear chain bases, } \\
\text { phenazine-like structure }\end{array}$ & [46] \\
\hline \multirow[t]{2}{*}{$1230 / 1235$} & $1230 / 1235$ & $\mathrm{n}(\mathrm{C}-\mathrm{N}), \mathrm{B}$ or polaron & linear chain & [46] \\
\hline & 1225 & $\mathrm{n}(\mathrm{C}-\mathrm{N}), \mathrm{B}$ or polaron & linear chain & {$[46,57,59,67]$} \\
\hline 1185 & 1190 & $\mathrm{~d}(\mathrm{C}-\mathrm{H}), \mathrm{Q}$ or polaron pair & $\begin{array}{l}\text { linear chain, aniline } \\
\text { cation radical }\end{array}$ & {$[49,57,58,60,61]$} \\
\hline $1175 / 1160$ & 1175 & $\mathrm{~d}(\mathrm{C}-\mathrm{H}), \mathrm{B}$ and SQ & linear chain & {$[46,57]$} \\
\hline
\end{tabular}


Table 3. Cont.

\begin{tabular}{|c|c|c|c|c|}
\hline $633 \mathrm{~nm}$ & $785 \mathrm{~nm}$ & Assignment & Typical Product & Reference \\
\hline $1150 / 1155$ & & $\mathrm{~d}(\mathrm{C}-\mathrm{H}), \mathrm{Phz}$ & $\begin{array}{c}\text { benzenoid ring, } \\
\text { phenazine-like structure }\end{array}$ & {$[18,28,46,57]$} \\
\hline 1055 & & $\mathrm{H} 2 \mathrm{SO} 4$ & $\mathrm{H} 2 \mathrm{SO} 4$ & [68] \\
\hline \multirow[t]{2}{*}{1045} & 1035 & $\mathrm{H} 2 \mathrm{SO} 4$, aniline & $\mathrm{H} 2 \mathrm{SO} 4$ & {$[60,68]$} \\
\hline & 1010 & $\mathrm{H} 2 \mathrm{SO} 4$ & $\mathrm{H} 2 \mathrm{SO} 4$ & [68] \\
\hline 1010 & 1010 & $\mathrm{H} 2 \mathrm{SO} 4$ & $\mathrm{H} 2 \mathrm{SO} 4$ & [68] \\
\hline 1000 & 1000 & $\mathrm{H} 2 \mathrm{SO} 4$, aniline & $\mathrm{H} 2 \mathrm{SO} 4$, aniline $++^{*}$ & [60] \\
\hline 960 & $970 / 980$ & $\mathrm{~d}$ (ring), $\mathrm{B}$ or polaron & linear chain & [46] \\
\hline \multirow[t]{2}{*}{880} & 880 & $\mathrm{~d}$ (ring), $\mathrm{Q}$ or polaron pair & linear chain & [46] \\
\hline & 868 & $\mathrm{~d}$ (ring), $\mathrm{Q}$ or polaron pair & linear chain & [46] \\
\hline \multirow[t]{2}{*}{840} & 850 & $\mathrm{~d}$ (ring), $\mathrm{Q}$ or polaron pair & linear chain & {$[58,61]$} \\
\hline & 830 & $\mathrm{~d}$ (ring) & linear chain & [46] \\
\hline \multirow[t]{2}{*}{810} & 810 & $\mathrm{~d}$ (ring) & linear chain, aniline & {$[57,60-62,69]$} \\
\hline & 805 & $\mathrm{~d}$ (ring) & linear chain & {$[57,61,62,69]$} \\
\hline 735 & 740 & $\mathrm{~d}(\mathrm{C}=\mathrm{N}-\mathrm{C})$ & linear chain bases & {$[46,57]$} \\
\hline 715 & 720 & $\mathrm{~d}(\mathrm{C}=\mathrm{N}-\mathrm{C})$ & linear chain bases & {$[46,57]$} \\
\hline 690 & 695 & & phenazine-like structure & {$[65,70]$} \\
\hline 655 & 660 & g(ring) SQ & linear chain & [39] \\
\hline 640 & 645 & g(ring), localized polaron & linear chain & {$[49,58]$} \\
\hline 610 & 610 & g(ring), $\mathrm{Phz}$ & phenazine-like structure & {$[28,58,61]$} \\
\hline 590 & 595 & & phenazine-like structure & {$[65,70]$} \\
\hline 590 & 585 & g(ring), Q & linear chain & [46] \\
\hline 575 & 575 & g(ring), polaron pair & $\begin{array}{c}\text { linear chain bases, } \\
\text { phenazine-like structure }\end{array}$ & [71] \\
\hline 550 & 545 & g(ring) & linear chain, aniline & [60] \\
\hline 530 & 525 & g(ring), $\mathrm{Q}$ or polaron pair & linear chain & {$[65,69,72]$} \\
\hline 515 & 515 & $\mathrm{~g}(\mathrm{~N}-\mathrm{H}), \mathrm{Q}$ or polaron pair & linear chain & {$[58,61]$} \\
\hline $495 / 505$ & 495 & g(ring) & $\begin{array}{c}\text { linear chain bases, } \\
\text { phenazine-like structure }\end{array}$ & {$[63,65,69]$} \\
\hline 465 & & g(ring) & & \\
\hline 430 & 425 & $\mathrm{~g}(\mathrm{C}-\mathrm{H}), \mathrm{Q}, \mathrm{t}(\mathrm{C}-\mathrm{N}-\mathrm{C})$ & linear chain & {$[58,61]$} \\
\hline 410 & 410 & $\mathrm{~g}(\mathrm{C}-\mathrm{H})$ & $\begin{array}{c}\text { linear chain bases, } \\
\text { phenazine-like structure }\end{array}$ & {$[58,61,63,69,73]$} \\
\hline 395 & 375 & g(ring), $Q$ & linear chain & {$[58,61]$} \\
\hline 295 & & $\mathrm{~g}(\mathrm{C}-\mathrm{N}-\mathrm{C})$ & $\begin{array}{l}\text { linear chain bases, } \\
\text { phenazine-like structure }\end{array}$ & [69] \\
\hline
\end{tabular}

Raman spectra obtained on SERS electrodes removed at various times from the reaction mixture of aniline oxidation starting at $\mathrm{pH} 1$ (Figure 6a, Table 3) are in line with the known pernigraniline route of aniline oxidation. At the beginning (electrode just dipped into the reaction mixture and rinsed with water right away) and after $2 \mathrm{~s}$, the spectra corresponding to linear AOs $(1627,1584,1390 / 1370$, $1175 \mathrm{~cm}^{-1}$ ) are observed [39,46,61] (Figure 7). Samples removed in the 2-20 min time window reflect the pernigraniline salt intermediate $\left(1627,1584,1495,1415,1382,1333,1225,1175 \mathrm{~cm}^{-1}\right)[63,67]$. The final spectrum represents the emeraldine salt $\left(1627,1603,1516,1382 / 1333,1175 \mathrm{~cm}^{-1}\right)[39,61]$. In the spectra obtained with the $633 \mathrm{~nm}$ excitation line (Figure $6 \mathrm{~b}$, Table 3), the spectral features of the quinonoid pernigraniline structure (mainly 1582 and 1491/1482 $\mathrm{cm}^{-1}$ ) are resonantly enhanced, thus, the spectrum 
of the final film is not dramatically different from the spectrum obtained after 20 minutes - residual overoxidated units are still detected.
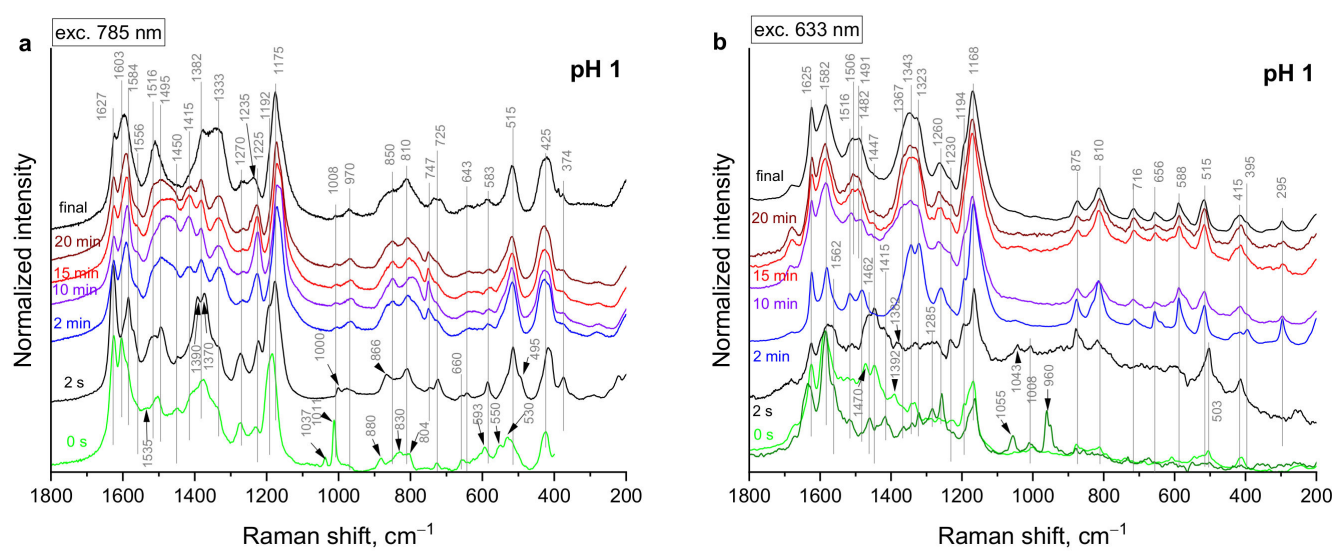

Figure 6. Raman spectra of gold SERS electrodes removed from the reaction mixture of starting $\mathrm{pH} 1$ at various times. Excitation $785 \mathrm{~nm}(\mathbf{a})$ and $633 \mathrm{~nm}(\mathbf{b})$.

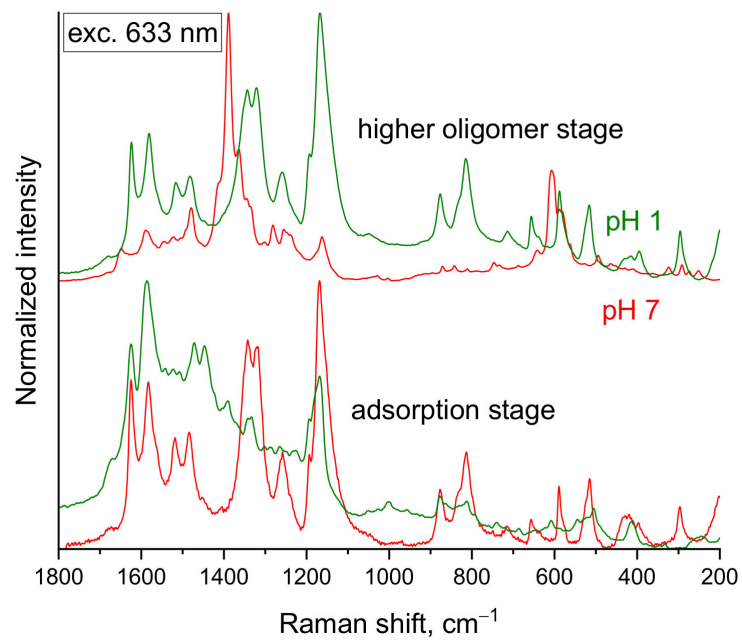

Figure 7. Raman spectra of gold SERS electrodes removed from the reaction mixture of starting $\mathrm{pH} 1$ and 7 at adsorption stage ( 2 resp. $5 \mathrm{~s}$ after mixing) and at higher oligomer stage (1.5 resp. 2 min after mixing). Excitation $633 \mathrm{~nm}$.

\subsection{Raman SEC of the Aniline Oxidation at $\mathrm{pH} 7$}

Electrochemical oxidation of aniline was followed in situ by SERS SEC. The voltamperogram of the aniline oxidation at $\mathrm{pH} 7$ (Figure 8a) shows only one oxidation peak at ca $0.4 \mathrm{~V}$, and an oxidation ramp of aniline to cation radical, while the electrochemical oxidation of aniline at $\mathrm{pH} 1$ shows only the aniline oxidation ramp (Figure $8 b$ ).

In the reduction phase, the $\mathrm{pH} 1$ sample displays the weak reduction peaks of PANI at ca $0.45,0.25$ and $-0.15 \mathrm{~V}$, while the $\mathrm{pH} 7$ reduction is flat, probably as the electrode is passivated by the AO layer.

The in-situ SERS SEC of aniline oxidation at $\mathrm{pH} 1$ (Figure 9) was thoroughly described elsewhere [18]. For the purpose of this paper, this experiment is used as a reference of linear AO redox behavior.

The Raman spectra of the products of the electrochemical aniline oxidation at $\mathrm{pH} 7$ (Figure 10) do not change much with potential; they mainly flatten due to increasing fluorescence typical for the non-protonated AO [17]. We will focus on the spectra excited with the $633 \mathrm{~nm}$ line, as it should lead to surface enhanced resonance Raman scattering (SERRS) enhancement of the charged phenazine-like 
oligomers [28], while the $785 \mathrm{~nm}$ excitation line resonantly enhances the spectral features of the linear oligomer fraction. The small changes are visualized with potential dependency plots (Figure 11).
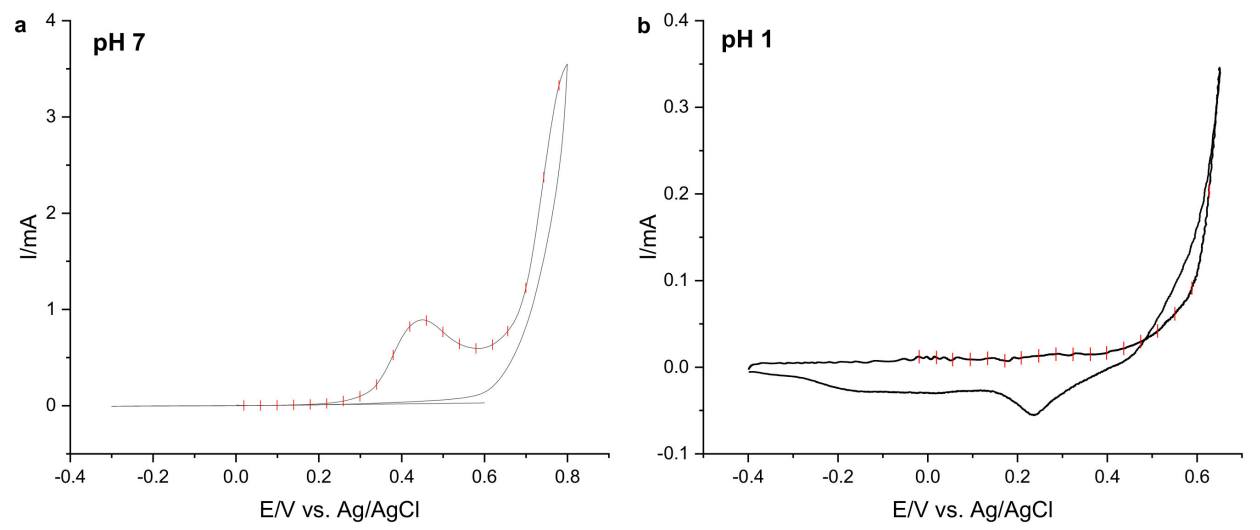

Figure 8. Electrochemical oxidation of aniline in aqueous medium of $\mathrm{pH}$ (a) 7 and (b) 1. Red marks separate potential ranges connected with one Raman spectrum.
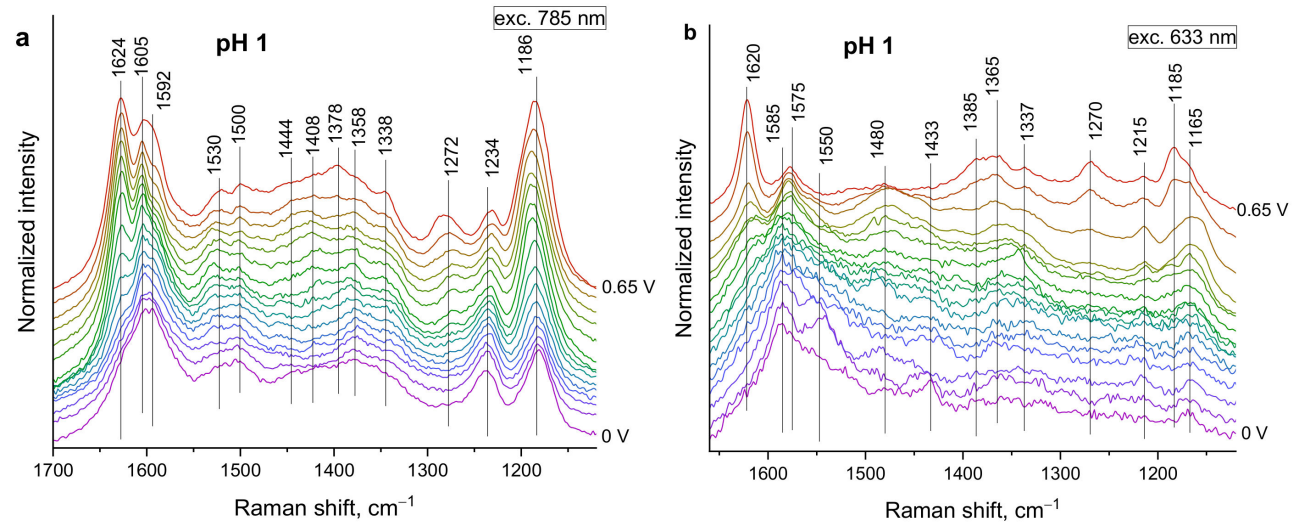

Figure 9. Raman spectra of gold SERS electrodes during the electrochemical oxidation of aniline in aqueous medium of $\mathrm{pH} 1$ (excitation $785 \mathrm{~nm}(\mathbf{a})$ and $633 \mathrm{~nm}(\mathbf{b})$ ).

The ring stretching mode shifts gradually from $1592 \mathrm{~cm}^{-1}$ (benzenoid ring (Table 3)) to $1598 \mathrm{~cm}^{-1}$ (charged semiquinonoid ring) (Figure 11a), implying gradual oxidation of the material deposited onto the electrode. The bands around $1170 \mathrm{~cm}^{-1}$ (C-H deformation on a benzenoid or semiquinonoid ring in a linear structure), $1592-1598 \mathrm{~cm}^{-1}$ (ring stretching of a semiquinonoid ring in a linear structure) and $1626 \mathrm{~cm}^{-1}$ (ring stretching of a benzenoid ring located next to a quinonoid ring in a linear structure) reach maximum intensity around $0.4 \mathrm{~V}$-the maximum of the oxidation peak (Figure 11b). These bands correspond to the emeraldine form of protonated PANI.

The intensity of the bands at $1348 \mathrm{~cm}^{-1}$ (C-H bending on a benzenoid ring in a PANI base) and $1565 \mathrm{~cm}^{-1}$ (ring stretching of a benzenoid ring in a PANI base) increase at potentials above $0.4 \mathrm{~V}$ (Figure 11c), implying the formation of the oxidized but neutral PANI base. 

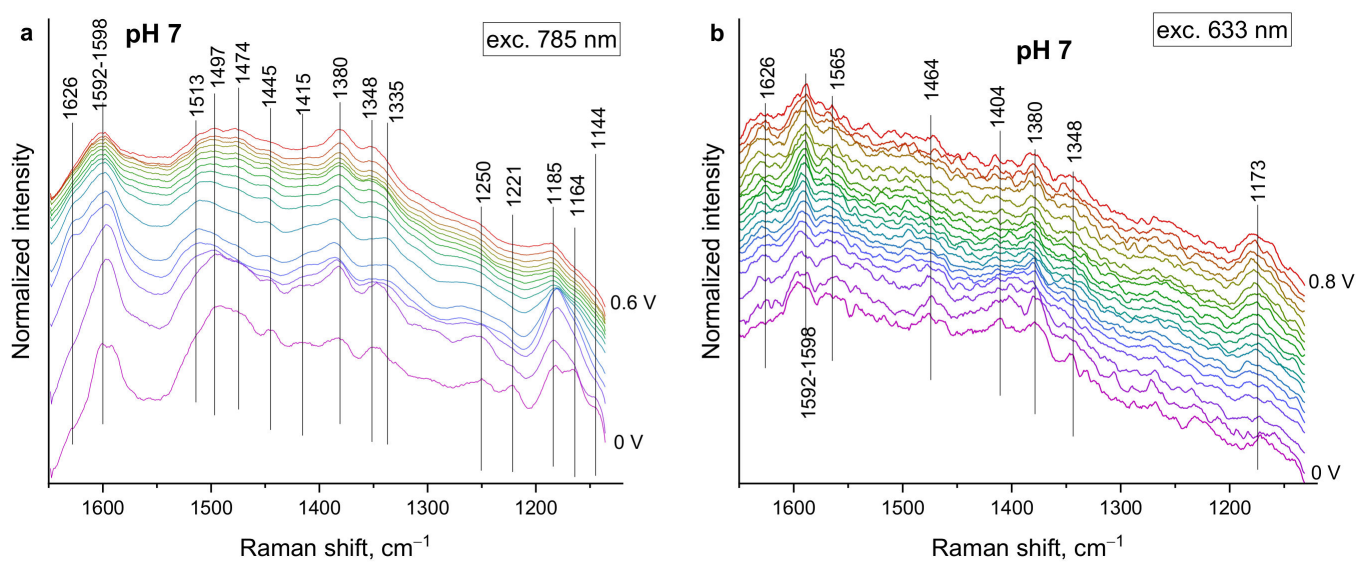

Figure 10. Raman spectra of gold SERS electrodes during the electrochemical oxidation of aniline in aqueous medium of pH 7 (excitation $785 \mathrm{~nm}(\mathbf{a})$ and $633 \mathrm{~nm}(\mathbf{b})$ ).
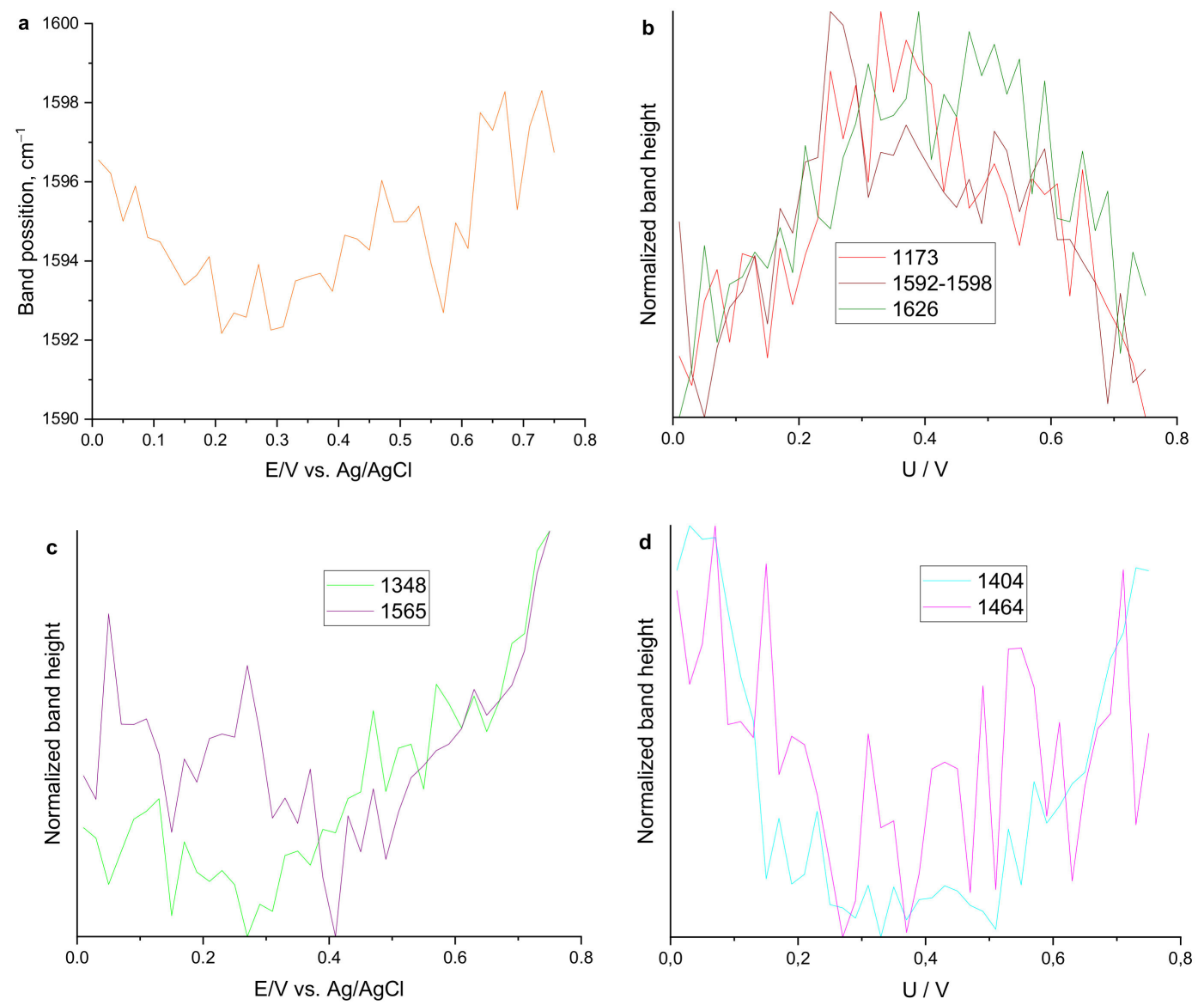

Figure 11. Potential dependencies of the position of the ring-stretching mode around $1600 \mathrm{~cm}^{-1}$ (a) and normalized band intensities of several changing bands during the electrochemical oxidation of aniline in aqueous medium of $\mathrm{pH} 7(\mathbf{b}-\mathbf{d})$. Excitation $633 \mathrm{~nm}$.

The bands at $1404 \mathrm{~cm}^{-1}$ (quinonoid ring stretching of PANI base) and $1464 \mathrm{~cm}^{-1}(\mathrm{C}=\mathrm{N}$ stretching) have minimum intensity around $0.4 \mathrm{~V}$ (Figure 11d). This is probably the result of the higher intensity of other bands around $0.4 \mathrm{~V}$.

From the in-situ aniline oxidation at $\mathrm{pH} 7$ we can conclude that a layer of a mixture of AO structures is formed on the electrode. The linear fraction, that is electroactive, is responsible for the changes observed in the Raman spectra. The high background is probably due to the ortho-linked AOs that tend to display fluorescence if not protonated [17]. 


\subsection{Raman SEC of the Film Prepared Electrochemically in Salt Solution, Conducted in $0.1 \mathrm{M} \mathrm{H}_{2} \mathrm{SO}_{4}$}

Even if the AOs formed in $\mathrm{pH} 7$ seem not to be very electroactive, this is not the case, as we illustrate by spectroelectrochemical study at $\mathrm{pH} 1$. As the AOs become protonated, changes of the Raman spectra with potential as well as oxidation and reduction peaks in CV appear. At potentials below $0.3 \mathrm{~V}$, we obtain a spectrum known for protonated phenazine-like AOs ( $\mathrm{N}$-phenylphenazinium cation) prepared chemically (Figure 9a). As the chemical oxidation of aniline is connected with a decrease of $\mathrm{pH}$, the AOs must at some point become protonated. This is not the case for electrochemical oxidation - the $\mathrm{N}$-phenylphenazinium cation features thus became visible after the electrolyte change. At higher potentials, the observed spectrum is identical to the spectra obtained during the electrochemical oxidation at $\mathrm{pH}$ 7. This process is probably connected with the oxidation peak around 0.3 resp. $0.2 \mathrm{~V}$ in the first resp. second oxidation run (Figure $12 \mathrm{~b}$ ). This peak has been previously connected with carbonyl defects $[23,32]$, therefore, the $\mathrm{AO}$ probably contains both $\mathrm{N}$-phenylphenazinium and benzoquinone unit in their structure (Figure $5 b$ ).

In a second oxidation run, the original Raman spectrum is not obtained. The main difference is the appearance of a band at $1394 \mathrm{~cm}^{-1}$ corresponding to $C \sim \mathrm{N}^{+}$stretching vibration, with a little more localized charge than in the case of the vibration peaking at $1371 \mathrm{~cm}^{-1}$.
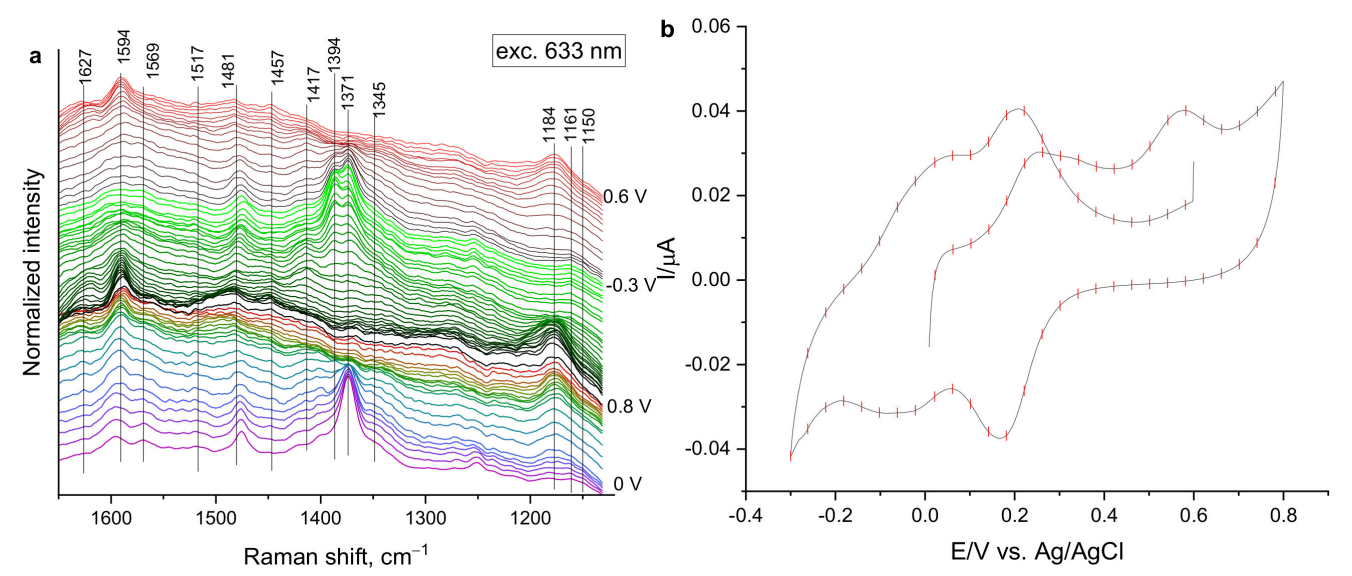

Figure 12. Raman spectra of gold SERS electrodes during the spectroelectrochemical study at $\mathrm{pH} 1$ of the AO formed electrochemically in an aqueous medium of $\mathrm{pH}$ 7. Excitation $633 \mathrm{~nm}$ (a) and the corresponding CV (b). Red marks separate potential ranges connected with one Raman spectrum.

The less obvious changes are visualized by the potential dependencies of the normalized intensities of selected bands (Figure 13). The intensity dependencies can be divided into three groups:

1. The peaks at $1150 \mathrm{~cm}^{-1}$ (C-H bending), $1161 \mathrm{~cm}^{-1}$ ( $\mathrm{C}-\mathrm{H}$ bending in a semiquinonoid structure), $1417 \mathrm{~cm}^{-1}\left(\mathrm{C} \sim \mathrm{N}\right.$ stretching in a highly localized polaron structures) and $1457 \mathrm{~cm}^{-1}(\mathrm{C}=\mathrm{N}$ stretching) reach maximum intensity around $0.2 \mathrm{~V}$ (Figure 13a). These bands are connected with the semiquinonoid-charged linear $\mathrm{AO}$.

2. The intensity of the peaks at $1184 \mathrm{~cm}^{-1}$ (C-H stretching in charged linear chain), $1569 \mathrm{~cm}^{-1}$ (benzenoid ring stretching in linear chains), $1594 \mathrm{~cm}^{-1}$ (semiquinonoid ring stretching) and $1627 \mathrm{~cm}^{-1}$ (quinonoid ring stretching) reach their maximum around $0.4 \mathrm{~V}$ (Figure 13b). These bands are connected with the quinonoid-charged linear AO.

3. The intensity of the peaks at $1345 \mathrm{~cm}^{-1}$ ( $\mathrm{C} \sim \mathrm{N}$ stretching in delocalized polaron structure), $1373 \mathrm{~cm}^{-1}$ (C $\sim \mathrm{N}$ structure in localized polaron structure), $1394 \mathrm{~cm}^{-1}$ (C N stretching in polaron pair structure), $1481 \mathrm{~cm}^{-1}$ ( $\mathrm{C}=\mathrm{N}$ stretching) and $1517 \mathrm{~cm}^{-1}$ (N-H deformation vibrations) decrease around $0.2 \mathrm{~V}$ (Figure 13c). These bands are connected with the $\mathrm{N}$-phenylphenazinium-based AO.

The changes in band intensities are hugely influenced by the fact that Raman scattering from the $\mathrm{N}$-phenylphenazinium cation-based structure is enhanced at gold SERS substrates at $633 \mathrm{~nm}$ excitation, 
and thereby it dominates the spectrum when present in this form-below $0.2 \mathrm{~V}$. The intensity changes above this point are mainly due to the redox changes of the linear AOs, always present in the mix.
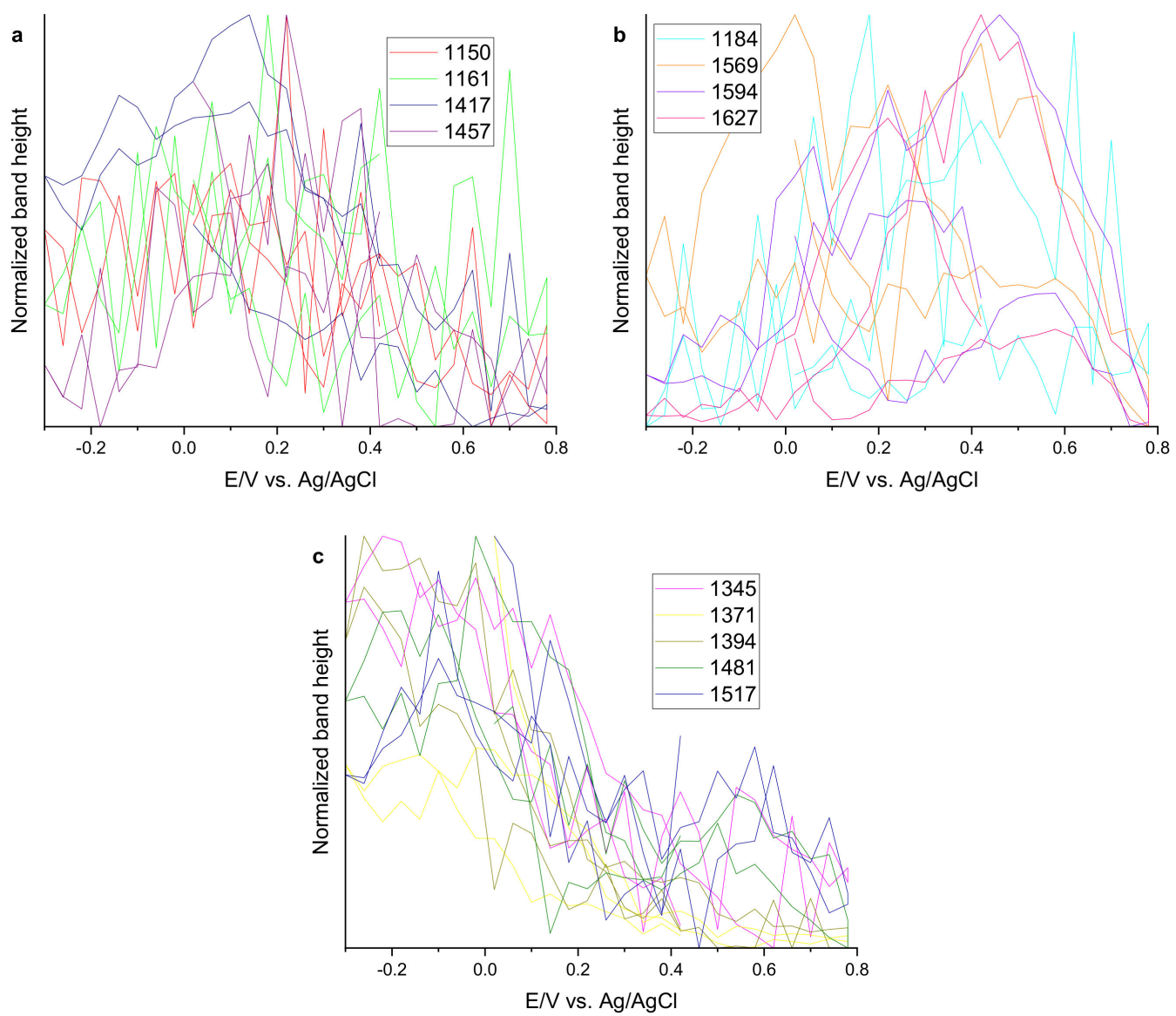

Figure 13. Potential dependencies of the normalized intensities of selected bands of semiquinonoid-charged linear $\mathrm{AO}$ (a), quinonoid-charged linear $\mathrm{AO}$ (b), and N-phenyl phenazinium-based $\mathrm{AO}$ (c) during the spectroelectrochemical study at $\mathrm{pH} 1$ of the aniline oligomer (AO) formed by electrochemical oxidation of aniline in aqueous medium of $\mathrm{pH} 7$. Excitation $633 \mathrm{~nm}$.

\section{Discussion}

The chemical oxidation of aniline at starting $\mathrm{pH} 1$ and 7 was followed by temperature, $\mathrm{pH}, \mathrm{OCP}$, FTIR in situ; UV-Vis and SERS ex situ.

The oxidation of aniline in acidic medium is already quite well known [24]. After mixing the aniline and APS solutions, an induction period of ca 3 min takes place. Formation of linear AOs in the oxidized state is observed by FTIR and SERS. Then the reaction rate increases, and the propagation of the pernigraniline chain is observed by all methods. After ca $15 \mathrm{~min}$, pernigraniline is reduced to emeraldine, as again observed by all methods. What is important, a well-adhering PANI film is formed, but no $\mathrm{N}$-phenylphenazinium or benzoquinone-based structures are observed at any stage of the chemical aniline oxidation started at $\mathrm{pH} 1$.

These structures are not necessary for the PANI film formation, and they are also not an inherent part of the process of chemical oxidation of aniline. The aniline couples strictly in the para positions, resulting in a linear polymer at low $\mathrm{pH}$, as proposed earlier $[16,17,19,22]$.

The oxidation of aniline at neutral starting $\mathrm{pH}$ was studied before in a couple of studies $[24,37]$. In this case, sodium sulfate salt was added to the reaction medium to ensure conductivity for the comparable electrochemical experiment. The reaction started immediately, as can be seen from temperature, $\mathrm{pH}$ and OCP kinetics. UV—Vis spectroscopy detected only $\mathrm{N}$-phenylphenazinium-based 
AOs after $100 \mathrm{~s}$ of reaction and later on. FTIR spectra of the reaction products remained unchanged during the reaction, and phenazine-like AOs were observed throughout the whole reaction time. Their protonation state cannot be identified from the FTIR spectra. Only in the first seconds, carbonyl groups were observed.

SERS, on the other hand, detected enormous changes during the aniline oxidation in the neutral medium: In the first seconds, linear AOs were observed. After $100 \mathrm{~s}, \mathrm{~N}$-phenylphenazinium cation and benzoquinone units absolutely dominated the spectrum. Later on, linear chain growth was observed in addition to the $\mathrm{N}$-phenylphenazinium cation-based AOs formation. It needs to be mentioned that neutral phenazine-like AOs do not produce well-resolved Raman spectra. A fluorescence background makes them virtually impossible to analyse with Raman spectroscopy. Once they become protonated, forming the $N$-phenylphenazinium cation, SERRS enhancement of these units becomes operative.

From our observations we can conclude that $\mathrm{N}$-phenylphenazinium-based AOs are by far the most dominant products of the reaction. However, they do not become protonated straight away. The protonation takes place after ca $100 \mathrm{~s}$, which corresponds to $\mathrm{pH}$ 5.5, according to the $\mathrm{pH}$ kinetics. Linear chain and benzoquinone-based AOs are minor components in the $\mathrm{AO}$ mixture.

The comparison between the chemical and electrochemical oxidation of aniline is based on SERS experiments. The in-situ SERS spectroelectrochemistry at $\mathrm{pH} 1$ was published earlier [18]. Here, we present an in-situ SERS spectroelectrochemical study of the aniline oxidation at $\mathrm{pH} 7$; and behavior of the formed product in a medium of $\mathrm{pH} 1$. The material formed on the electrode at $\mathrm{pH} 7$ is not very electroactive, wherein only weak redox features of the linear AO fraction was observed. The SERS spectra of the material lack any distinguishable/significant features. The spectra also did not change very much with potential; the changes can be assigned to the linear $\mathrm{AO}$ fraction. In addition, the spectra were obscured by fluorescence, which is typical for the neutral form of the $\mathrm{N}$-phenyl phenazine structure. However, after the change of the electrolyte to acidic medium ( $0.1 \mathrm{M}$ sulfuric acid), both CV and Raman spectra changed radically as the AOs became protonated. Typical N-phenylphenazinium Raman features were observed below ca $0.2 \mathrm{~V}$. At this potential, the $\mathrm{N}$-phenylphenazinium cations become oxidized, and their Raman scattering is not enhanced any more. Above this potential, the linear AO fraction dominates the Raman spectrum.

\section{Conclusions}

We have demonstrated that $N$-phenylphenazinium cation-based AOs do not form at low $\mathrm{pH}$ in any amount, not even during the chemical oxidation of aniline. $N$-phenylphenazinium cation-based AOs are thus not an inherent part of the chemical oxidation of aniline. This makes the in-situ chemical preparation of PANI films equal to the electrochemical PANI film formation concerning the linearity of the PANI chains.

The $\mathrm{N}$-phenyl phenazine-based AO was the main product of both the chemical and electrochemical oxidation of aniline at $\mathrm{pH}$. When protonated, the $\mathrm{N}$-phenylphenazinium cation-based AO becomes electroactive, non-fluorescent and SERS-enhanced. In the chemical oxidation of aniline started at $\mathrm{pH} 7$, the protonation of the $\mathrm{N}$-phenyl phenazine structure becomes protonated after ca $100 \mathrm{~s}$, where after the $\mathrm{pH}$ drops to ca 5.5. The electrochemical aniline oxidation proceeds at constant $\mathrm{pH}$, so the formed $\mathrm{AO}$ layer does not become protonated during formation in neutral medium. When protonated artificially by the change of electrolyte to $0.1 \mathrm{M}$ sulfuric acid, the $\mathrm{N}$-phenylphenazinium cation was detected. As the $\mathrm{N}$-phenyl phenazine-based $\mathrm{AO}$ was protonated and electroactive, its electrochemical behavior could be studied.

It has one oxidation peak at ca $0.2 \mathrm{~V}$. Below this potential, $N$-phenylphenazinium cation-based AOs are observed by SERRS. Above this potential, the SERRS enhancement of the phenazine-like AOs is turned off; leading to the dominance of the linear AO fraction in the Raman spectra.

Author Contributions: The investigation was conducted by all of the authors; the manuscript was written mainly by Z.M. All authors have read and agreed to the published version of the manuscript. 
Funding: This research was funded by the Czech Science Foundation; grant number 18-01924Y.

Conflicts of Interest: The authors declare no conflict of interest.

\section{References}

1. Nasar, A.; Mashkoor, F. Application of polyaniline-based adsorbents for dye removal from water and wastewater-A review. Environ. Sci. Pollut. Res. 2019, 26, 5333-5356. [CrossRef] [PubMed]

2. Escandari, E.; Kosari, M.; Farahani, M.H.D.A.; Khiavi, N.D.; Saeedikhani, M.; Katal, R.; Zarinejad, M. A review on polyaniline-based materials applications in heavy metals removal and catalytic processes. Separ. Purif. Tech. 2020, 231, 1-27. [CrossRef]

3. Sinha, A.; Kalambate, P.K.; Mugo, S.M.; Kamau, P.; Chen, J.; Jain, R. Polymer hydrogel interfaces in electrochemical sensing strategies: A review. TrAC 2019, 118, 488-501.

4. Shoaie, N.; Daneshpour, M.; Azimzadeh, M.; Mahshid, S.; Khoshfetrat, S.M.; Jahanpeyma, F.; Gholaminejad, A.; Omidfar, K.; Foruzandeh, M. Electrochemical sensors and biosensors based on the use of polyaniline and its nanocomposites: A review on recent advances. Microchim. Acta 2019, 186, 1-29. [CrossRef]

5. Zamani, F.G.; Moulahoum, H.; Ak, M.; Demirkol, D.O.; Timur, S. Current trends in the development of conducting polymers-based biosensors. TrAC 2019, 118, 264-276.

6. Wang, Y.; Liu, A.; Han, Y.; Li, T. Sensores based on conductive polymers and their composites: A review. Polym. Int. 2019, 69, 7-17. [CrossRef]

7. Distler, T.; Boccaccini, A.R. 3D printing of electrically conductive hydrogels for tissue engineering and biosensors-A review. Acta Biomater. 2020, 101, 1-13. [CrossRef]

8. Zare, E.N.; Makvandi, P.; Ashtari, B.; Rossi, F.; Motahari, A.; Perale, G. Progress on conductive polyaniline-based nanocomposites for biomedical applications: A review. J. Med. Chem. 2020, 63, 1-22. [CrossRef]

9. Cho, S.; Lee, J.S.; Joo, H. Recent developments of the solution-processable and highly conductive polyaniline composites for optical and electrochemical applications. Polymers 2019, 11, 1-17. [CrossRef]

10. Banerjee, J.; Dutta, K.; Kader, M.A.; Nayak, S.K. An overview on the recent developments in polyaniline-based supercapacitors. Polym. Adv. Tech. 2019, 30, 1902-1921. [CrossRef]

11. Liu, Z.; Yuan, X.; Zhang, S.; Wang, J.; Huang, Q.; Yu, N.; Zhu, Y.; Fu, L.; Wang, F.; Chen, Y.; et al. Three-dimensional ordered porous electrode materials for electrochemical energy storage. NPG Asia Mater. 2019, 11, 1-21. [CrossRef]

12. Luo, Y.; Guo, R.; Li, T.; Li, F.; Liu, Z.; Zheng, M.; Wang, B.; Yang, Z.; Luo, H.; Wan, Y. Application of polyaniline for Li-ion batteries, lithium-sulfur batteries, and supercapacitors. ChemSusChem 2019, 12, 1591-1611. [CrossRef] [PubMed]

13. Wang, Y.; Ding, Y.; Guo, X.; Yu, G. Conductive polymers for stretchable supercapacitors. Nano Res. 2019, 12, 1978-1987. [CrossRef]

14. Stejskal, J.; Sapurina, I. Polyaniline: Thin films and colloidal dispersions (IUPAC Technical Report). Pure Appl. Chem. 2005, 77, 815-826. [CrossRef]

15. Gvozdenović, M.M.; Jugović, B.Z.; Stevanović, J.S.; Trišović, T.L.; Grgur, B.N. Electrochemical polymerization of aniline. In Electropolymerization; InTech: London, UK, 2011; pp. 77-96.

16. Jangid, N.K.; Jadoun, S.; Kaur, N. A review on high-throughput synthesis, deposition of thin films and properties of polyaniline. Eur. Polym. J. 2020, 125, 1-17. [CrossRef]

17. Stejskal, J.; Trchová, M. Aniline oligomers versus polyaniline. Polym. Int. 2012, 61, 240-251. [CrossRef]

18. Morávková, Z.; Dmitrieva, E. The First Products of Aniline Oxidation-SERS Spectroelectrochemistry. ChemistrySelect 2019, 30, 8847-8854. [CrossRef]

19. Ćirić-Marjanović, G.; Konyushenko, E.N.; Trchová, M.; Stejskal, J. Chemical oxidative polymerization of anilinium sulfate versus aniline: Theory and experiment. Synth. Met. 2008, 158, 200-211. [CrossRef]

20. Sapurina, I.; Stejskal, J. The mechanism of the oxidative polymerization of aniline and the formation of supramolecular polyaniline structures. Polym. Int. 2008, 57, 1295-1325. [CrossRef]

21. Gospodinova, N.; Terlemezyan, L. Conducting polymers prepared by oxidative polymerization: Polyaniline. Prog. Polym. Sci. 1998, 23, 1443-1484. [CrossRef] 
22. Ćirić-Marjanović, G. Recent advances in polyaniline research: Polymerization mechanisms; structural aspects; properties and applications. Synth. Met. 2013, 177, 1-47. [CrossRef]

23. Ferreira, D.C.; Pires, J.R.; Temperini, M.L.A. Spectroscopic characterization of oligoaniline microspheres obtained by an aniline-persulfate approach. J. Phys. Chem. B 2011, 115, 1368-1375. [CrossRef] [PubMed]

24. Stejskal, J.; Sapurina, I.; Trchová, M.; Konyushenko, E.N. Oxidation of aniline: Polyaniline granules; nanotubes; and oligoaniline microspheres. Macromolecules 2008, 41, 3530-3536. [CrossRef]

25. Stejskal, J.; Sapurina, I.; Trchová, M. Polyaniline nanostructures and the role of aniline oligomers in their formation. Prog. Polym. Sci. 2010, 35, 1420-1482. [CrossRef]

26. Sapurina, I.; Ochsadev, A.Y.; Volchek, B.Z.; Trchová, M.; Riede, A.; Stejskal, J. In-situ polymerized polyaniline films: 5. Brush-like chain ordering. Synth. Met. 2002, 129, 29-37. [CrossRef]

27. Tomšík, E.; Morávková, Z.; Stejskal, J.; Trchová, M.; Zemek, J. In situ polymerized polyaniline films: The top and the bottom. Synth. Met. 2012, 162, 2401-2405. [CrossRef]

28. Trchová, M.; Morávková, Z.; Dybal, J.; Stejskal, J. Detection of aniline oligomers on polyaniline-gold intarface using resonance Raman scattering. ACS Appl. Mater. Interfaces 2014, 6, 942-950. [CrossRef]

29. Morávková, Z.; Stejskal, J.; Trchová, M. Spectrodcopic study of the highly homogeneous polyaniline film formation on gold support. Spectrochim. Acta Part. A 2016, 152, 294-303. [CrossRef]

30. Dinh, H.N.; Ding, J.; Xia, S.J.; Birss, V.I. Multi-technique study of the anodic degradation of polyaniline films. J. Electroanal. Chem. 1998, 459, 45-56. [CrossRef]

31. Gao, P.; Gosztola, D.; Weaver, M.J. Surface-enhanced Raman spectroscopy as a probe of electroorganic reaction pathways. 2. Ring coupling mechanisms during aniline oxidation. J. Phys. Chem. 1989, 93, 3753-3760. [CrossRef]

32. Dmitrieva, E.; Dunsch, L. How linear is "linear" polyaniline? J. Phys. Chem. B 2011, 115, 6401-6411. [CrossRef] [PubMed]

33. Li, R.L.; Lin, C.-W.; Shao, Y.; Chang, C.W.; Yao, F.-K.; Kowal, M.D.; Wang, H.; Yeung, M.T.; Huang, S.-C.; Kaner, R.B. Characterization of aniline tetramer by MALDI TOF mass spectrometry upon oxidative and reductive cycling. Polymers 2016, 8, 1-11. [CrossRef] [PubMed]

34. Holze, R. Adsorption of aniline on gold: A SERS study. J. Electroanal. Chem. 1988, 250, 143-157. [CrossRef]

35. Šeděnková, I.; Trchová, M.; Stejskal, J. In Situ Infrared Spectroscopy of Oligoaniline Intermediates Created under Alkaline Conditions. J Phys. Chem. B 2014, 118, 14972-14981.

36. Liu, Y.C.; Wang, C.C.; Tsai, C.E. Effects of electrolytes used in roughening gold substrates by oxidation-reduction cycles on surface-enhanced Raman scattering. Electrochem. Commun. 2005, 7, 1345-1350. [CrossRef]

37. Trchová, M.; Šeděnková, I.; Konyushenko, E.N.; Stejskal, J.; Holler, P.; Ćirić-Marjanović, G. Evolution of Polyaniline Nanotubes: The Oxidation of Aniline in Water. J. Phys. Chem. B 2006, 110, 9461-9468. [CrossRef]

38. Ćirić-Marjanović, G.; Trchová, M.; Konyushenko, E.N.; Holler, P.; Stejskal, J. Chemical oxidative polymerization of aminodiphenylamines. J. Phys. Chem. B 2008, 112, 6976-6987. [CrossRef]

39. Boyer, M.I.; Quillard, S.; Louarn, G.; Froyer, G.; Lefrant, S. Vibrational study of the $\mathrm{FeCl}_{3}$-doped dimer of polyaniline; A good model compound of emeraldine salt. J. Phys. Chem. B 2000, 104, 8952-8961. [CrossRef]

40. Ping, Z. In situ FTIR-attenuated total reflection spectroscopic investigations on the base-acid transitions of polyaniline. Base-acid transition in the emeraldine form of polyaniline. J. Chem. Soc. Faraday Trans. 1996, 92, 3063-3067. [CrossRef]

41. Silva, C.H.B.; Ferreira, D.C.; Ando, R.A.; Temperini, M.L.A. Aniline-1.;4-benzoquinone as a model system for the characterization of products from aniline oligomerization in low acidic media. Chem. Phys. Lett. 2012, 551, 130-133. [CrossRef]

42. Surwade, S.P.; Dua, V.; Manohar, N.; Manohar, S.K.; Beck, E.; Ferris, J.P. Oligoaniline intermediates in the aniline-peroxydisulfate system. Synth. Met. 2009, 259, 445-455. [CrossRef]

43. Socrates, G. Infrared and Raman Characteristic Group Frequencies; Wiley: New York, NY, USA, 2001.

44. Šeděnková, I.; Trchová, M.; Stejskal, J. Thermal degradation of polyaniline films prepared in solutions of strong and weak acids and in water-FTIR and Raman spectroscopic studies. Polym. Degrad. Stab. 2008, 93, 2147-2157. [CrossRef]

45. Trchová, M.; Stejskal, J. Polyaniline: The infrared spectroscopy of conducting polymer nanotubes (IUPAC Technical Report). Pure Appl. Chem. 2011, 83, 1803-1817. [CrossRef] 
46. Boyer, M.I.; Quillard, S.; Rebourt, E.; Louarn, G.; Buisson, J.P.; Monkman, A.; Lefrant, S. Vibrational analysis of polyaniline: A model compound approach. J. Phys. Chem. B 1998, 102, 7382-7392. [CrossRef]

47. Ping, Z.; Nauer, G.E.; Neugebauer, H.; Theiner, J.; Neckel, A. Protonation and electrochemical redox doping processes of polyaniline in aqueous solutions: Investigations using in situ FTIR-ATR spectroscopy and a new doping system. J. Chem. Soc. Faraday Trans. 1997, 93, 121-129. [CrossRef]

48. Cao, Y. Spectroscopic studies of acceptor and donor doping of polyaniline in the emeraldine base and pernigraniline forms. Synth. Met. 1990, 35, 319-332. [CrossRef]

49. Quillard, S.; Louarn, G.; Buisson, J.P.; Boyer, M.; Lapkowski, M.; Pron, A.; Lefrant, S. Vibrational spectroscopic studies of the isotope effects in polyaniline. Synth. Met. 1997, 84, 805-806. [CrossRef]

50. Huang, W.S.; MacDiarmid, A.G. Optical properties of polyaniline. Polymer 1993, 34, 1833-1845. [CrossRef]

51. Xia, Y.; Weisinger, J.M.; MacDiarmid, A.G. Camphorsulfonic acid fully doped polyaniline emeraldine salt: Conformations in different solvents studied by an ultraviolet/visible/neer-infrared spectroscopic method. Chem. Mater. 1995, 7, 443-445. [CrossRef]

52. Folch, S.; Régis, A.; Gruger, A.; Colomban, P. Chain length effect on intrachain electronic excitaion and interchain coupling in poly- and oligoanilines. Synth. Met. 2000, 110, 219-227. [CrossRef]

53. Gruger, A.; El Khalki, A.; Colomban, P. Protonation.; sol formation and precipitation of poly- and oligoanilines. J. Raman Spectrosc. 2003, 34, 438-450. [CrossRef]

54. Bilal, S.; Holze, R. In situ UV-vis spectroelectrochemistry of poly (o-phenylenediamine-co- $m$-toluidine). Electrochim. Acta 2007, 52, 5346-5356. [CrossRef]

55. Ding, Z.; Sanchez, T.; Labouriau, A.; Iyer, S.; Larson, T.; Currier, R.; Zhao, Y.; Yang, D. Characterisation of reaction intermediate aggregates in aniline oxidative polymerization at low proton concentracion. J. Phys. Chem. B 2010, 114, 10337-10346. [CrossRef] [PubMed]

56. Dmitrieva, E.; Harima, Y.; Dunsch, L. Influence of Phenazine Structure on Polaron Formation in Polyaniline: In Situ Electron Spin Resonance-Ultraviolet/Visible-Near-Infrared Spectroelectrochemical Study. J. Phys. Chem. B 2009, 113, 16131-16141. [CrossRef]

57. Louarn, G.; Lapkowski, M.; Quillard, S.; Pron, A.; Buisson, J.P.; Lefrant, S. Vibrational properties of polyaniline-isotope effects. J. Phys. Chem. 1996, 100, 6998-7006. [CrossRef]

58. Cochet, M.; Louarn, G.; Quillard, S.; Boyer, M.I.; Buisson, J.P.; Lefrant, S. Theoretical and experimental vibrational study of polyaniline in base forms: Non-planar analysis. Part I. J. Raman Spectrosc. 2001, 31, 1029-1039. [CrossRef]

59. de Santana, H.; Quillard, S.; Fayad, E.; Louarn, G. In situ UV-vis and Raman spectroscopic studies of the electrochemical behavior of N,N'-diphenyl-1,4-phenylenediamine. Synth. Met. 2006, 156, 81-85. [CrossRef]

60. Wojciechowski, P.M.; Zierkiewicz, W.; Michalska, D.; Hobza, P. Electronic structures; vibrational spectra; and revised assignment of aniline and its radical cation: Theoretical study. J. Chem. Phys. 2003, 118, 10900-10911. [CrossRef]

61. Cochet, M.; Louarn, G.; Quillard, S.; Buisson, J.P.; Lefrant, S. Theoretical and experimental vibrational study of emeraldine in salt form. Part II. J. Raman Spectrosc. 2000, 31, 1041-1049. [CrossRef]

62. Panicker, C.Y.; Varghese, H.M.; Anto, P.L.; Daizy, P.J. Potential dependent SERS profile of sulfanilic acid on silver electrode. J. Raman Spectrosc. 2006, 37, 853-857. [CrossRef]

63. Ćirić-Marjanović, G.; Trchová, M.; Stejskal, J. The oxidative polymerization of aniline in water: Raman spectroscopy. J. Raman Spectrosc. 2008, 39, 1375-1387. [CrossRef]

64. Anto, P.L.; Panicker, C.Y.; Varghese, H.T.; Philip, D.J. Potential-dependent SERS profile of orthanilic acid on silver electrode. J. Raman Spectrosc. 2006, 37, 1265-1271. [CrossRef]

65. Sestrem, R.H.; Ferreira, D.C.; Landers, R.; Temperini, M.L.A.; do Nascimento, G.M. Synthesis and spectroscopic characterisation of polymer and oligomers of o-phenylenediamine. Eur. Polym. J. 2010, 46, 484-493. [CrossRef]

66. Morávková, Z.; Dmitrieva, E. Structureal changes in polyaniline near the middle oxidation peak studied by in situ Raman spectroelectrochemistry. J. Raman Spectrosc. 2017, 48, 1229-1234. [CrossRef]

67. Furukawa, Y.; Ueda, F.; Hyodo, Y.; Harada, I.; Nakajima, T.; Kawagoe, T. Vibrational spectra and structure of polyaniline. Macromolecules 1988, 21, 1297-1305. [CrossRef]

68. Malinowski, E.R.; Cox, R.A.; Haldna, U.L. Factor analysis for isolation of the Raman spectra of aqueous sulfuric acid components. Anal. Chem. 1984, 56, 778-781. [CrossRef] 
69. Colomban, P.; Folch, S.; Gruger, A. Vibrational study of short-range order and structure of polyaniline bases and salts. Macromolecules 1999, 32, 3080-3092. [CrossRef]

70. Brolo, A.G.; Sanderson, A.C. Surface-enhanced Raman scattering (SERS) from a silver electrode modified with oxazine 720. Can. J. Chem. 2004, 82, 1474-1480. [CrossRef]

71. do Nascimento, G.M.; Silva, C.H.B.; Temperini, M.L.A. Electronic structure and doping behavior of PANI-NSA nanofibers investigated by resonance Raman spectroscopy. Macromol. Rapid Commun. 2006, 27, 255-259. [CrossRef]

72. do Nascimento, G.M.; Pereira da Silva, J.E.; Cordoba de Torresi, S.I.; Temperini, M.L.A. Comparison of Secondary Doping and Thermal Treatment in Poly (diphenylamine) and Polyaniline Monitored by Resonance Raman Spectroscopy. Macromolecules 2002, 35, 121-125. [CrossRef]

73. Takahashi, M.; Goto, M.; Ito, M. Surface-enhanced Raman scattering of phenazine. Large intensities of overtones and combination bands. Chem. Phys. Lett. 1985, 121, 458-493. [CrossRef]

(C) 2020 by the authors. Licensee MDPI, Basel, Switzerland. This article is an open access article distributed under the terms and conditions of the Creative Commons Attribution (CC BY) license (http://creativecommons.org/licenses/by/4.0/). 